\title{
Comparative biochemistry of four polyester (PET) hydrolases
}

\author{
Arnling Bååth, Jenny; Borch, Kim; Jensen, Kenneth ; Brask, Jesper; Westh, Peter
}

Published in:

ChemBioChem

Link to article, DOI:

$10.1002 /$ cbic. 202000793

Publication date:

2021

Document Version

Peer reviewed version

Link back to DTU Orbit

Citation (APA):

Arnling Bååth, J., Borch, K., Jensen, K., Brask, J., \& Westh, P. (2021). Comparative biochemistry of four polyester (PET) hydrolases. ChemBioChem, 22(9), 1627-1637. https://doi.org/10.1002/cbic.202000793

\section{General rights}

Copyright and moral rights for the publications made accessible in the public portal are retained by the authors and/or other copyright owners and it is a condition of accessing publications that users recognise and abide by the legal requirements associated with these rights.

- Users may download and print one copy of any publication from the public portal for the purpose of private study or research.

- You may not further distribute the material or use it for any profit-making activity or commercial gain

- You may freely distribute the URL identifying the publication in the public portal

If you believe that this document breaches copyright please contact us providing details, and we will remove access to the work immediately and investigate your claim 


\section{ChemBioChem}

Combining Chemistry and Biology

\section{Phemistry Europe}

European Chemical Societies Publishing

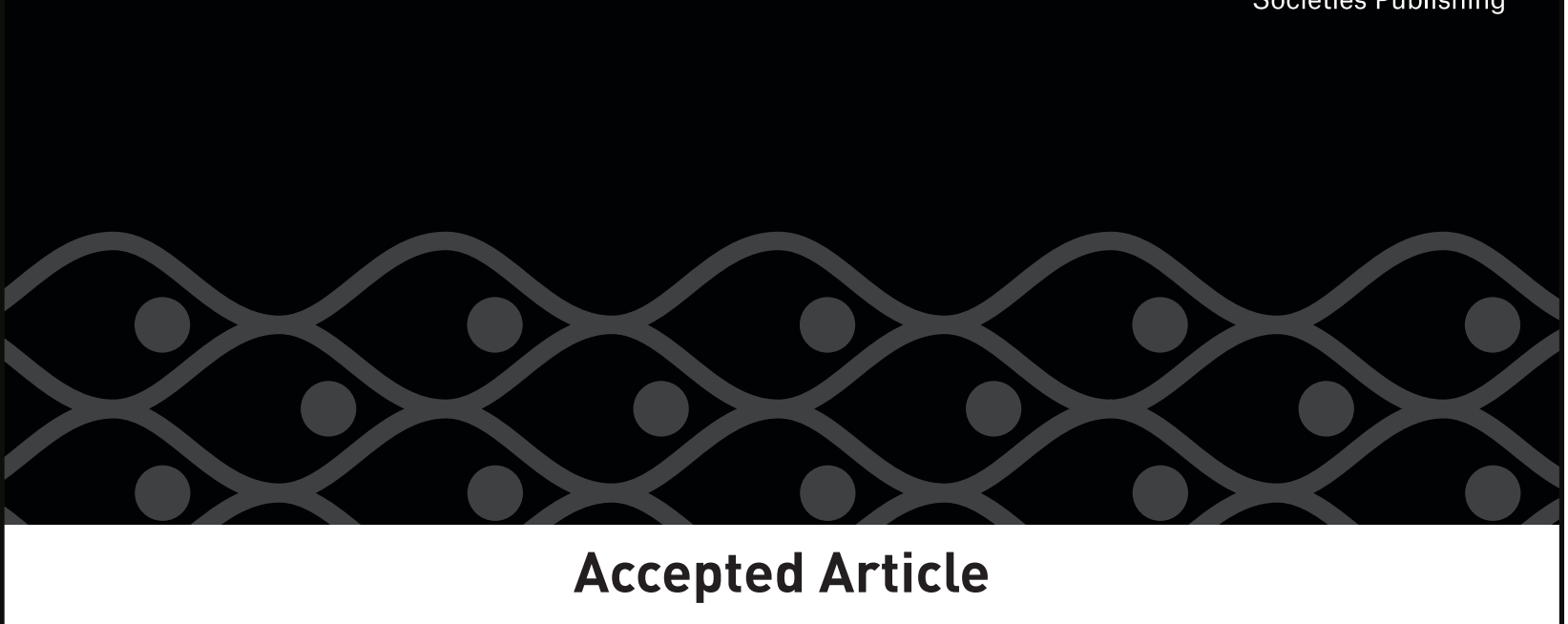

Title: Comparative biochemistry of four polyester (PET) hydrolases

Authors: Jenny Arnling Bååth, Kim Borch, Kenneth Jensen, Jesper Brask, and Peter Westh

This manuscript has been accepted after peer review and appears as an Accepted Article online prior to editing, proofing, and formal publication of the final Version of Record (VoR). This work is currently citable by using the Digital Object Identifier (DOI) given below. The VoR will be published online in Early View as soon as possible and may be different to this Accepted Article as a result of editing. Readers should obtain the VoR from the journal website shown below when it is published to ensure accuracy of information. The authors are responsible for the content of this Accepted Article.

To be cited as: ChemBioChem 10.1002/cbic.202000793

Link to VoR: https://doi.org/10.1002/cbic.202000793 


\title{
Comparative biochemistry of four polyester (PET) hydrolases
}

\author{
Jenny Arnling Bååth ${ }^{1}$, Kim Borch $^{2}$, Kenneth Jensen $^{2}$, Jesper Brask $^{2}$ and Peter Westh ${ }^{1 *}$
}

${ }^{1}$ Department of Biotechnology and Biomedicine, Technical University of Denmark, Søltofts Plads, DK2800 Kgs. Lyngby, Denmark

${ }^{2}$ Novozymes A/S, Biologiens Vej 2, DK-2800 Kgs. Lyngby, Denmark

*Corresponding author: Peter Westh

E-mail: petwe@dtu.dk

Running title: Comparative biochemistry of PET hydrolases

Keywords: Enzyme kinetics, Michaelis-Menten, cutinase, PET hydrolase, serine esterase, enzyme turnover, enzyme degradation, biotechnology, interfacial enzymology, heterogeneous catalysis 


\begin{abstract}
The potential of bioprocessing in a circular plastic economy has strongly stimulated research in enzymatic degradation of different synthetic polymers. Particular interest has been devoted to the commonly used polyester, poly(ethylene terephthalate) (PET), and a number of PET hydrolases have been described. However, a kinetic framework for comparisons of PET hydrolases (or other plastic degrading enzymes) acting on the insoluble substrate, has not been established. Here, we propose such a framework and test it against kinetic measurements on four PET hydrolases. The analysis provided values of $\mathrm{k}_{\text {cat }}$ and $\mathrm{K}_{\mathrm{M}}$, as well as an apparent specificity constant in the conventional units of $\mathrm{M}^{-1} \mathrm{~s}^{-1}$. These parameters, together with experimental values for the number of enzyme attack sites on the PET surface, enabled comparative analyses. A variant of the PET hydrolase from Ideonella sakaiensis was the most efficient enzyme at ambient conditions, which relied on a high $\mathrm{k}_{\text {cat }}$ rather than a low $\mathrm{K}_{\mathrm{M}}$. Moreover, both soluble and insoluble PET fragments were consistently hydrolyzed much faster than intact PET. This suggests that interactions between polymer strands slow down PET degradation, while the chemical steps of catalysis and the low accessibility associated with solid substrate were less important for the overall rate. Finally, the investigated enzymes showed a remarkable substrate affinity, and reached half the saturation rate on PET, when the concentration of attack sites in the suspension was only about $50 \mathrm{nM}$. We propose that this is linked to nonspecific adsorption, which promotes the nearness of enzyme and attack sites.
\end{abstract}

\section{Introduction}

Polyethylene terephthalate (PET) is a copolymer of terephthalic acid (TPA) and ethylene glycol (EG) linked by ester bonds (Fig. 1), and among the most produced plastics. The stable nature of the PET molecule has been an advantage for its use in fibers, films and packaging, but this characteristic is also becoming an increasing problem, as it leads to accumulation of PET in the environment (1-3). This causes a growing need for cost-effective means to recycle PET waste for example through monomer recovery and re-synthesis of virgin residue. Recent progress suggests that this may be achieved through bioprocessing (1,4), and one crucial requirement for this is the development of efficient enzymes for PET degradation.

Research on enzymatic degradation of PET has been ongoing for over 20 years, and enzymes classified as cutinases have been described as the most promising PET hydrolases $(2,3,5)$. Cutinases are typical serine hydrolases, with an $\alpha / \beta$ fold and a catalytic triad consisting of serine, histidine and aspartate (6). Compared to lipases and many esteractive enzymes, cutinases exhibit a flat, surface exposed active site, and this have been described as essential for their interaction with the PET polymer, which is bulkier than their preferred, aliphatic substrate, cutin $(7,8)$. PET hydrolases have been described as enzymes with low to moderate turnover rates, reflecting the fact that PET is an unnatural substrate for these enzymes (2). However, in 2016 the bacterium Ideonella sakaiensis was discovered, possessing an unprecedented capacity to use PET as a source of carbon and energy. This bacterium was isolated from a PET-rich environment and secretes a PET hydrolase, which is homologous to cutinases. Due to its superior PET degrading ability and a significantly lower activity on natural, aliphatic polyesters it has been categorized into a novel family of enzymes, named PETases (EC 3.1.1.101) (5). The discovery of the I. sakaiensis PETase has led to several structural studies, which have improved our understanding of the catalytic process and consequently outlined strategies for rational engineering of enzyme variants with improved activity against the synthetic substrate (9-12). However, this progress in structural understanding has not been paralleled by biochemical investigations. Thus, while some studies have reported kinetic parameters for PET hydrolases $(4,8,13-17)$, most functional assessments have used long contact times and empirical discussions of either end-point concentrations or progress curves (18-23). Results from the latter type of work primarily elucidate time- and dose requirements to achieve a significant degree of polymer conversion, and are hence important for technical applications of PET hydrolases. However, in the absence of 
physically meaningful kinetic parameters, one can typically only make superficial analyses of structure-function relationships. This makes it difficult to compare results across different studies, and impedes the potential for interpretations regarding molecular mechanisms of the catalytic process.

The scarcity of kinetic parameters can be linked to the interfacial nature of the reaction, which gives rise to some complications that are unknown in conventional (bulk) enzyme kinetics. One particular difficulty arises because the molar concentration of the substrate is unknown. This challenges the use of mass-action kinetics and hence the conventional Michaelis-Menten ( $\left.{ }^{\text {conv }} \mathrm{MM}\right)$ framework $(8,24)$. However, mass-action kinetics is widely used for non-biochemical, interfacial catalysis $(25,26)$, and the normal way to handle the solid material in rate equations is to define a number of sites on the surface, which are competent for the process in question. Along these lines, we define an attack site on the PET surface as a locus, where the PET hydrolase is able to form a productive substrate complex (Fig. 2). If the density of attack sites, $\Gamma_{\text {attack }}$ in units of mol sites per gram PET, can be experimentally established, it is possible to convert a substrate load (in $\mathrm{g} / \mathrm{L}$ ) into a molar concentration of sites (27). This is only an apparent molar concentration, because the surface sites are not evenly distributed in the suspension, but the approach opens up for the use of massaction kinetics, and hence the derivation of rigorous kinetic parameters for a heterogeneous enzyme reaction. We note that the problem of deriving kinetic parameters for enzymes acting on insoluble substrate has been addressed in different ways, including the use of surface area or mass load to specify the amount of substrate in rate equations $(24,28)$. This has provided important progress, but in general, kinetic parameters obtained in this way attain odd units and are hard to compare outside the experimental conditions under which they are measured. In addition, $\Gamma_{\text {attack }}$ has the advantage that it is derived from the kinetic measurements and hence uses the enzyme itself to probe surface accessibility under the given conditions (solution, particle size etc.). One obvious limitation of this approach is that it should only be used in experiments with a low degree of substrate conversion as $\Gamma_{\text {attack }}$ will change as the reaction progresses. However, if the progress curve is linear, such conversion dependent changes are likely small.

In the current work, we have tested a kinetic approach based on these ideas for PET hydrolases. Specifically, we analyzed rate measurements obtained under two different experimental conditions. One set of data was made in the usual limit of substrate excess, while the other was made under condition of enzyme excess. For interfacial enzyme reactions, the steady-state approximation may be justified for both of these conditions (29), and the latter, so-called inverse Michaelis-Menten ( ${ }^{\text {inv }} \mathrm{MM}$ ) framework, has occasionally been used for solid substrates (30-32) including PET $(8,14,15)$. Both ${ }^{\text {conv }} \mathrm{MM}$ plots (rate vs. substrate load) and ${ }^{\text {inv }} \mathrm{MM}$ plots (rate vs. enzyme concentration) may lead to hyperbolic curves (27), and the benefit of combining these two approaches may be illustrated by considering the conditions at saturation. For

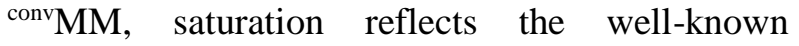
situation, where all enzyme are engaged in a complex, and the rate becomes (c.f. Fig. 2)

${ }^{\text {conv }} \mathrm{V}_{\max }=\mathrm{k}_{\mathrm{cat}} \mathrm{E}_{0}$

For ${ }^{\text {inv }} \mathrm{MM}$, saturation occurs at high enzyme concentration as all attack sites on the surface become occupied (and additional enzyme accumulates in the bulk). If we assume that the conversion of these sites is governed by $\mathrm{k}_{\text {cat }}$, the inverse saturation rate may be written

${ }^{\text {inv }} \mathrm{V}_{\text {max }}=\mathrm{k}_{\mathrm{cat}} \Gamma_{\text {attack }} \mathrm{S}_{0}$

where $S_{0}$ is the (known) mass load of substrate. The expression in eq. (2) emerges intuitively as illustrated in Fig. 2, but has been derived rigorously elsewhere (27). As ${ }^{\text {conv }} V_{\max }$ and ${ }^{\text {inv }} V_{\max }$ can be derived from experiments, we can estimate $\Gamma_{\text {attack }}$ as the ratio of the maximal specific rates. Specifically, combining eqs. (1) and (2) yields

$\frac{\frac{\operatorname{snv}_{V_{\max }}}{S_{0}}}{\frac{\mathrm{conv}_{V_{\max }}}{E 0}}=\Gamma_{\text {attack }}$ 
We have used these ideas to characterize a group of enzymes consisting of a catalytically improved variant of I. sakaiensis PETase (12), cutinases from respectively the fungus Humicola insolens and the bacterium Thermobifida fusca and a carboxylesterase from Bacillus subtilis. These enzymes have previously been reported to hydrolyze PET $(8,14,21)$ and here we conduct a comparative kinetic analysis with respect to their activity on both polymeric PET and smaller (soluble or insoluble) model substrates, primarily PET fragments. We also report a conspicuous effect of the nonionic surfactant $n$-dodecyl $\beta$-D-maltoside (DDM) on the kinetic parameters of these enzymes. The results provide novel insights into the enzymatic degradation of PET, and we hope that the suggested kinetic approach may serve as inspiration for further developments of comparative approaches within this rapidly growing and technically important area of enzymology.

\section{Results}

We measured hydrolytic rates of two wild type cutinases (HiC and TfC), a variant of the $I$. sakaiensis PETase (S238F/W159H, herein called IsP) and one carboxyl-esterase (BsCE) on both polymeric PET and a number of small ester substrates and PET fragments (see Fig. 1 for substrate structures). In addition, we studied the influence of the nonionic surfactant DDM on the enzyme kinetics. This surfactant was chosen due to the absence of (hydrolysable) ester bonds and aromatic groups that could interfere with the UV measurements (present in e.g. the commonly used detergents Triton X-100 and tween). The hydrolysis of PET was quantified by the increment of UV absorption in the supernatant detected in a plate reader, while activity on smaller substrates required RP-HPLC-based detection. The plate reader-based detection method relies on assumptions discussed elsewhere, but is feasible for comparative studies (33). We made conv $\mathrm{MM}$ analysis for all substrates. Specifically, reaction rates were plotted as a function of the load or concentration of substrate and analyzed with respect to the ${ }^{\text {conv }} \mathrm{MM}$ equation, eq. (4).

$v=\frac{\operatorname{conv}_{V}{ }^{\max } S_{0}}{\operatorname{conv}_{M}+S_{0}}$
For the insoluble substrates PET and BETEB, we also conducted experiments with enzyme excess. In these cases, the reaction rates were plotted as a function of the enzyme concentration and analyzed with respect to the inv MM equation, eq. (5) (27)

$v=\frac{i n v_{V}{ }^{\max } E_{0}}{i n v K_{M}+E_{0}}$

\section{Steady-state kinetics with PET as substrate}

Three of the investigated enzymes (HiC, TfC and IsP) showed distinct activity on suspended PET powder, while no product release was detected for BsCE after $24 \mathrm{~h}$ incubation at $50{ }^{\circ} \mathrm{C}$. BsCE has previously been described as an enzyme that acts on PET films, but this was based on experiments with $120 \mathrm{~h}$ contact time and over ten-fold higher enzyme concentration than in the current study (21). Hence, we conclude that BsCE performs poorly on polymeric PET compared to $\mathrm{HiC}$, TfC and IsP, which could be a result of its 3D architecture with a deep active site cleft, compared to the flat and surface exposed active site of cutinases. This supports earlier suggestions that esterases as well as lipases (with an active-site lid structure) are inferior PET hydrolases. In order to decide on suitable contact times for activity measurements for the three PET-active enzymes, we made progress curves with excess of either PET or enzyme (Fig. S2). Incubation times within the linear range of these progress curves were deemed appropriate for determination of steady-state rates. The three PETactive enzymes were investigated at different temperatures below the midpoint of thermal denaturation, $\mathrm{T}_{\mathrm{m}}$. At $\mathrm{pH} 8, \mathrm{~T}_{\mathrm{m}}$ was $66^{\circ} \mathrm{C}$ for $\mathrm{HiC}$, $80{ }^{\circ} \mathrm{C}$ for $\mathrm{TfC}, 55^{\circ} \mathrm{C}$ for IsP and $56^{\circ} \mathrm{C}$ for BsCE.

Representative rate measurements are illustrated as conventional- (Fig. 3) and inverse- (Fig. 4) MM plots, and parameters derived by fitting respectively eq. (4) or eq. (5) are listed in Table 1 ( ${ }^{\text {conv }} \mathrm{MM}$ ) and Table 2 (inv $\mathrm{MM})$. The two equations generally accounted well for the data except in the case of ${ }^{\text {inv }} \mathrm{MM}$ for IsP. As shown in Fig. 4, this system showed the expected behavior at low enzyme concentrations, but declining rates at higher enzyme dosages. A similar behavior has been 
observed previously both for another cutinase hydrolyzing PET (17) and for enzymes hydrolyzing the natural polyester poly[(R)-3-hydroxybutyrate] (PHB). This has been explained by bulk aggregation, "overcrowding" of enzymes to the substrate surface (34-36), but also as an effect of a rapid reduction of available surface area due to fast enzymatic hydrolysis (28). Finally, the correlation of high surface coverage and denaturation is widely observed for adsorbed populations of marginally stable proteins (37).

Some general trends in Tables 1 and 2 may be worth emphasizing. We found, for example, that well known efficacy of IsP against PET $(38,39)$ relies on rapid turnover $\left(\mathrm{k}_{\text {cat }}\right.$ is 1-2 orders of magnitude larger than for the two cutinases) rather than a particular affinity for the substrate ${ }^{\left({ }^{c o n v}\right.} \mathrm{K}_{\mathrm{M}}$ values are comparable). Another trend in Table 1 is a conspicuous increase of both ${ }^{\text {conv }} \mathrm{K}_{\mathrm{M}}$ and $\mathrm{k}_{\text {cat }}$ upon the addition of a very low concentration of the nonionic surfactant DDM $(50 \mu \mathrm{M}$, i.e. below the critical micelle concentration). Conversely, DDM had little effect on the parameters in the inverse regime.

In addition to the parameters in Tables 1 and 2, which result directly from non-linear regression, it is useful to consider some derived kinetic parameters. These include the attack site density,

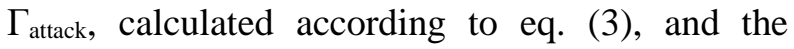
catalytic efficacy (or specificity constant), ${ }^{\text {mass }} \eta=\mathrm{k}_{\text {cat }}{ }^{\text {conv }} \mathrm{K}_{\mathrm{M}}$. The superscript of the specificity constant specifies that it is in mass based units, and we will discuss this further below (c.f. eq. (8)). Values of $\Gamma_{\text {attack }}$ and mass $\eta$ for $\mathrm{HiC}$, TfC and IsP acting on PET with or without DDM are listed in Table 3 .

\section{Steady-state kinetics with BETEB as substrate}

BETEB (Fig. 1b) may be seen as a fragment of a PET chain, and it has previously been used as a model substrate (21) for PET hydrolases. It is insoluble in water (equilibrium concentration in buffer could not be detected with the current methods), and we therefore used suspended substrate, and the same kinetic approaches as in the experiments with PET. We did not use surfactant in the experiments with BETEB. Products from BETEB hydrolysis were quantified by RP-HPLC, where peaks corresponding to the retention time of BA were dominant in all cases (Fig. S3). We hence used the built-up of BA to specify the steady-state rate. Like in the case of PET, we found that BsCE was essentially unable to hydrolyze BETEB. Results from ${ }^{\text {conv }} \mathrm{MM}$ and ${ }^{\text {inv }} \mathrm{MM}$ measurements for the three other enzymes and their analysis by eqs. (4) and (5) respectively are illustrated in Fig. 5.

Kinetic parameters derived from Fig. 5 are listed in Table 4, and these data showed that HiC, TfC and IsP have values of ${ }^{\text {conv }} K_{M}$ that are similar and close to those observed with PET as substrate. In contrast to this similarity, turnover numbers on BETEB were orders of magnitudes larger than on PET. Finally, the density of attack sites on the BETEB surface was significantly higher than on PET.

\section{Steady-state kinetics on soluble substrates}

Activity measurements of PET hydrolases on soluble substrates are convenient, but not generally indicative of the PET degrading capacity (5). Here, we included kinetic studies on $p \mathrm{NP}$-val, MHET and BHET (see Fig. 1 for structures). Detailed data are presented in the Supporting information in the form of (conventional) MM plots (Fig. S4), and the calculated kinetic parameters $\mathrm{K}_{\mathrm{M}}(\mathrm{mM})$ and $\mathrm{k}_{\mathrm{cat}}\left(\mathrm{s}^{-1}\right)$ (Table S1). The specificity constants are presented in Table 5. The results show that $\mathrm{HiC}$, TfC and BsCE hydrolyze $p$ NP-val quite efficiently with $\eta$ values between $2 \times 10^{4}$ and $2 \times 10^{5} \mathrm{M}^{-1} \mathrm{~s}^{-1}\left(\mathrm{k}_{\text {cat }}\right.$ values were between $4 \mathrm{~s}^{-1}$ and $30 \mathrm{~s}^{-1}$, Table S1). Table 5 also shows that none of the tested enzymes prefer MHET as substrate, but that all of them (particularly BsCE with $\eta=2 \times 10^{4} \mathrm{M}^{-1} \mathrm{~s}^{-1}$ ) are active on BHET. Finally, Table 5 confirms earlier reports $(5,38)$, that IsP has very low activity against $p$ NPval.

\section{Discussion}

Bioprocessing provides a promising tool in the fight against the immense environmental problems 
associated with an escalating consumption of plastic (7). The most progressed example is the use of enzymatic degradation of PET waste for recycling (4), and one requirement for this application is the design of better enzymes. This includes both better catalytic activity against the unnatural substrates and optimization with regards to relevant process conditions. Rational attempts to accomplish this will rely on a better understanding of structure-function relationships and formal kinetics makes up a key element in this respect. Nevertheless, formal kinetics with physically meaningful parameters remain scarce for plastic degradation and in the current work we propose and test a framework for this.

\section{Maximal turnover}

The specific reaction rate at enzyme saturation, $\mathrm{k}_{\mathrm{cat}}={ }^{\mathrm{conv}} \mathrm{V}_{\text {max }} / \mathrm{E}_{0}$, was determined for both soluble and insoluble substrates (Tables 1, 4 and S1). It appeared that the two cutinases $\mathrm{HiC}$ and TfC were quite slow on the semi-crystalline, polymeric PET, with $\mathrm{k}_{\text {cat }}$ values at $50{ }^{\circ} \mathrm{C}$ corresponding to a few turnovers per minute (Table 1). IsP was significantly faster, with a $\mathrm{k}_{\text {cat }}$ of approximately 40 $\mathrm{min}^{-1}$ at $50{ }^{\circ} \mathrm{C}$ (and even $30 \mathrm{~min}^{-1}$ at $40{ }^{\circ} \mathrm{C}$ ). It might be so that IsP is superior in hydrolyzing PET substrates of higher crystallinity than the other cutinases, but due to the enzyme's instability at higher temperatures, the phenomenon of increased catalytic rates when approaching PET's glass transition temperature cannot be investigated. Nevertheless, these values may be compared with specific rates from some earlier reports. Tournier et al. (2020) included TfC (BTA hydrolase 1 in their terminology) in an extensive study of PET hydrolases (4). They used amorphous PET particles of a similar size as the current, and reported specific rates corresponding to respectively $0.02 \mathrm{~s}^{-1}\left(50^{\circ} \mathrm{C}\right)$ and $0.07 \mathrm{~s}^{-1}\left(60{ }^{\circ} \mathrm{C}\right)$. These values compare very well with $\mathrm{k}_{\text {cat }}$ for $\mathrm{TfC}$ in Table 1 . Tournier et al. did not report $\mathrm{K}_{\mathrm{M}}$ values so we cannot say whether these specific rates reflect enzyme saturation, but the substrate load was $2 \mathrm{~g} / \mathrm{L}$, which is above $\mathrm{K}_{\mathrm{M}}$ values found here, so the results probably represent reasonable estimates of $\mathrm{k}_{\text {cat. }}$ Barth et al. (2015), on the other hand, found a much higher turnover number of about $2 \mathrm{~s}^{-1}$ at $60{ }^{\circ} \mathrm{C}$ for a related cutinase from T. fusca (13). This latter work used PET nanoparticles (about $100 \mathrm{~nm}$ ) as substrate, and the higher turnover calls for further investigations of relationships between maximal turnover and particle size.

We consistently observed much higher $\mathrm{k}_{\text {cat }}$ values on the model substrate BETEB. Specifically, the three enzymes with activity on PET (HiC, TfC and IsP) showed quite similar $\mathrm{k}_{\text {cat }}$ on BETEB in the range of $2-5 \mathrm{~s}^{-1}$ at $50{ }^{\circ} \mathrm{C}$ (Table 4). For TfC, this is two orders of magnitude faster than its turnover number on PET, and for $\mathrm{HiC}$ and IsP it is one order of magnitude faster. It is interesting to notice that this difference in $\mathrm{k}_{\text {cat }}$ occurred although both PET and BETEB are insoluble, and this obviously suggests that the interfacial nature of the reaction does not per se dictate a slow turnover. This interpretation is further supported by comparisons with $\mathrm{k}_{\text {cat }}$ values for the same enzymes acting on the soluble PET fragments MHET and BHET. These latter turnover numbers (Table S1) were comparable to those found on BETEB, and again contradicts any direct correlation between insoluble substrate and slow turnover. It is also of interest to compare the observed $\mathrm{k}_{\text {cat }}$ values with typical values for enzymes acting on their preferred, natural substrate. For esterases, a survey of the BRENDA database suggested that $\mathrm{k}_{\mathrm{cat}}$ values for native, soluble substrates predominantly fell in the $3-30 \mathrm{~s}^{-}$ 1 range (40), and other meta-analyses covering wider selections of enzymes have found similar average $\mathrm{k}_{\text {cat }}$ values $(41,42)$. We note that the $\mathrm{k}_{\text {cat }}$ values found here for different PET fragments (whether soluble or insoluble) were in this range. This may be unexpected for $\mathrm{HiC}$ and $\mathrm{TfC}$, which (unlike IsP) are probably devoid of any evolutionary adaptation to the substrate. Overall, these observations indicate that the turnover rate of intact PET depends on interactions in the polymeric substrate, whereas the chemical steps associated with the hydrolytic reaction (which are common to PET and its fragments) are comparably fast. Thus, interactions between polymer strands in the solid substrate could result in large activation barriers for complexation or dissociation, and hence slow down the overall process, even if the actual hydrolytic reaction is fast (as indicated by $\mathrm{k}_{\text {cat }}$ values for PET fragments). Analogous arguments have previously 
been put forward in discussions of the (slow) enzymatic hydrolysis of cellulose $(43,44)$.

\section{Specificity constants}

The overall efficacy of enzymes (natural or engineered) that act on anthropogenic substrates is typically gauged by the specificity constant (45). For insoluble substrates this parameter is readily calculated according to eq. (6)

${ }^{\text {mass }} \eta=\mathrm{k}_{\mathrm{cat}}{ }^{\text {conv }} \mathrm{K}_{\mathrm{M}}$

The superscript designates that this definition leads to specificity constants in mass-based units (in the current case $\left.(\mathrm{g} / \mathrm{L})^{-1} \mathrm{~s}^{-1}\right)$, and the application of mass $\eta$ defined in this way, is essentially limited to comparisons of isoenzymes acting on the same substrate. Here, we found that ${ }^{\text {mass }} \eta$ for IsP $\left(\approx 3 \mathrm{~s}^{-}\right.$ ${ }^{1}(\mathrm{~g} / \mathrm{L})^{-1}$ at $\left.50{ }^{\circ} \mathrm{C}\right)$ was much higher than ${ }^{\text {mass }} \eta$ for $\mathrm{HiC}$ and $\mathrm{TfC}$, and this again testifies the superior performance of IsP on PET. The specificity constants on BETEB were higher and quite similar for the three enzymes (between 10 and $40 \mathrm{~s}^{-1}(\mathrm{~g} / \mathrm{L})^{-1}$ at $50{ }^{\circ} \mathrm{C}$ ). In other words, IsP appeared distinctly superior to the two cutinases on polymeric PET, but not on the shorter BETEB substrate. For a broader discussion of specificity constants, we converted the mass $\eta$ values to the conventional units of $\mathrm{M}^{-1} \mathrm{~s}^{-1}$. Specifically, we used the attack site density, $\Gamma_{\text {attack}}$, from Table 3 to calculate the Michaelis constant, ${ }^{\text {conv }} \mathrm{K}_{\mathrm{M}}$, in molar units, (i.e. moles of attack sites per liter suspension at half saturation)

${ }^{\text {molar }} \mathrm{K}_{\mathrm{M}}={ }^{\text {conv }} \mathrm{K}_{\mathrm{M}} \Gamma_{\text {attack }}$

Combining eqs. (6) and (7) yields an expression for the molar specificity constant, ${ }^{\text {molar }} \eta$

${ }^{\text {molar }} \eta=\mathrm{k}_{\mathrm{cat}} /{ }^{\text {molar }} \mathrm{K}_{\mathrm{M}}={ }^{\text {mass }} \eta / \Gamma_{\text {attack }}$

Specificity constants for the insoluble substrates were calculated according to eq. (8) and are listed in Table 6 . We used the symbol molar $\eta$ to indicate that these values were derived indirectly. Nevertheless, we will discuss them together with specificity constants for soluble substrates (denoted $\eta$ in Table 5) calculated in the normal way.
If we first consider soluble substrates, we found very low specificity constants on MHET for all investigated enzymes, while the values on BHET were in the range from $10^{3}$ to $10^{4} \mathrm{M}^{-1} \mathrm{~s}^{-1}$. To put this into perspective, we note that the majority of enzymes acting on their preferred, natural substrate have specificity constants of $10^{4}$ to $10^{6} \mathrm{M}^{-1} \mathrm{~s}^{-1}$ (42). The smaller specificity constants for soluble PET fragments indicates that these are poor substrates for most of the enzymes investigated here, even if $\mathrm{k}_{\text {cat }}$ is fairly high (see above). The only clear exception for this is BHET hydrolysis by BsCE, which showed a specificity constant $\left(2 \times 10^{4} \mathrm{M}^{-1} \mathrm{~s}\right.$ $\left.{ }^{1}\right)$ comparable to (the low end of) natural enzymesubstrate systems. Interestingly, ${ }^{\text {molar }} \eta$-values for insoluble substrates were larger than $\eta$ for the soluble PET fragments. Thus, for $\mathrm{HiC}$ and TfC, molar $\eta$ attained values of $10^{7}$ and $10^{5} \mathrm{M}^{-1} \mathrm{~s}^{-1}$, respectively, on polymeric PET at $50{ }^{\circ} \mathrm{C}$. Unfortunately, the value for IsP could not be determined due to the problems of finding the inverse maximal rate (see Fig. 4), but estimates based on the highest directly measured rate in Fig. 4 , suggest that ${ }^{\text {molar }} \eta$ is at least $10^{6} \mathrm{M}^{-1} \mathrm{~s}^{-1}$ for IsP on PET. High specificity constants for the degradation of soluble, synthetic compounds have been observed before (see (45) for a review), but it is noteworthy that this parameter increased for insoluble substrates. While the exact meaning of ${ }^{\text {molar }} \eta$ remains to be elucidated, one possible explanation is that the enzyme adsorbs nonspecifically on the hydrophobic surface of the substrate particles. If indeed so, enzymes will concentrate near the attack sites and hence experience a higher effective substrate concentration compared to bulk reactions. In essence, this means that the reaction space is reduced from $3 \mathrm{D}$ to $2 \mathrm{D}$. This interpretation finds some support in the observation of very strong, non-specific adsorption of cutinases on other types of (non-hydrolysable) plastic $(46,47)$. It is also worth noting that similar molar $\eta$ values have been reported earlier for other interfacial enzyme reactions. Specifically, hydrolysis of (insoluble) microcrystalline cellulose by the cellulases Cel6A and Cel7A showed ${ }^{\text {molar }} \eta$ in the range of $10^{5}$ to $10^{6}$ $\mathrm{M}^{-1} \mathrm{~s}^{-1}(48,49)$. These cellulases have separate carbohydrate binding modules (CBM), which promotes strong surface adsorption, and this again suggests a link between adsorption and high 
${ }^{\text {molar }} \eta$ of interfacial reactions. Interestingly, CBMs also show affinity for PET surfaces, and fusion proteins with a cutinase and a CBM have shown improved activity against PET (50,51). Possible relationships between adsorption and the specificity constant may be further illustrated by considering the two terms in eq. (8) $\left(\mathrm{k}_{\mathrm{cat}}\right.$ and $\left.{ }^{\text {molar }} \mathrm{K}_{\mathrm{M}}\right)$ separately. As discussed above, $\mathrm{k}_{\text {cat }}$ for $\mathrm{HiC}$ and $\mathrm{TfC}$ on PET were much lower than typical values for enzymes modifying their innate substrate, and it follows that the high values of ${ }^{\text {molar }} \eta$ rely on an unusually low ${ }^{\text {molar }} \mathrm{K}_{\mathrm{M}}$. To illustrate this, we inserted data for HiC and TfC acting on PET at $50{ }^{\circ} \mathrm{C}$ into eq. (7). This gave ${ }^{\text {molar }} \mathrm{K}_{\mathrm{M}}$ values of $30-40 \mathrm{nM}$ for both enzymes, and it follows that the hydrolytic rate reaches half its maximal value, when there are some $40 \mathrm{nmol}$ attack sites per liter suspension. This is a sign of a very strong substrate interaction. Thus, $\mathrm{K}_{M}$ for wild type enzymes catalyzing naturally occurring reactions in the bulk phase predominantly fall in the range between $10 \mu \mathrm{M}$ and $1 \mathrm{mM}(42)$. We propose that this anomalously low $\mathrm{K}_{\mathrm{M}}$ could be mediated by nonspecific adsorption to the PET surface, which promotes the encounter of enzyme and substrate.

\section{Attack site densities and effects of surfactant}

Many earlier studies of enzymatic PET degradation have adopted the use of surfactants in the protocols. This has served different purposes including modification of enzyme-substrate interactions, cleaning of the PET surface or simply experimental convenience in the preparation and handling of PET suspensions $(14,23,50,52-54)$. To systematically test the effect of a nonionic surfactant, we repeated both the conventional- and inverse MM measurements on the PET substrate in a buffer that was supplemented with DDM. We found that even a low surfactant concentration (ca. $50 \mu \mathrm{M}$ ), imparted strong and systematic effects on the

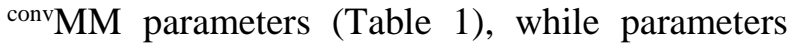
from the inv $\mathrm{MM}$ measurements (Table 2) were only marginally affected. Specifically, ${ }^{\text {conv }} \mathrm{K}_{\mathrm{M}}$ and $\mathrm{k}_{\mathrm{cat}}$ increased in the presence DDM, and this meant that we could not always reach saturation in the ${ }^{\text {conv }} \mathrm{MM}$ measurements (in particular the ${ }^{\text {conv }} \mathrm{MM}$ curve for IsP at $40{ }^{\circ} \mathrm{C}$, was almost linear, see lower right panel in Fig. 3). Therefore, the conventional kinetic parameters with DDM are only approximate, but the increase was distinctive (Fig. 3). The effect of the surfactant also emerged as a marked reduction of the number of attack sites recognized by the enzymes (Table 3 ). These observations may bring some clues of the underpinning mechanisms. Thus, the results are in line with the interpretation that DDM accumulates on the hydrophobic PET surface, and hence screen a fraction of the attack sites. This may explain both the lowered $\Gamma_{\text {attack}}$, and the increased ${ }^{\text {conv }} \mathrm{K}_{\mathrm{M}}$, as a higher mass-load of PET would be required to reach half-saturation if some attack sites are covered. Interestingly, negative effects of surface coverage are compensated by an increase in $\mathrm{k}_{\text {cat }}$, and the overall picture is that DDM leads to fewer, but more rapidly converted complexes. Molecular origins of this compensation remains to be investigated, but it could be related to unproductive binding of enzyme. Thus, if a fraction of the enzymes adsorbs nonproductively (or with poor productivity), $\mathrm{k}_{\mathrm{cat}}$ will reflect a weighted average of active and inactive populations. Nonionic surfactants are known to reduce nonspecific adsorption, and this could diminish putative populations of nonproductively bound enzyme and hence raise the observed $\mathrm{k}_{\text {cat }}$. At any rate, the pronounced effects of DDM call for more systematic investigations of this area both with respect to molecular mechanism and potential significance for bioprocessing of polyester. Some important work using either anionic- or cationic surfactants has pointed towards changed electrostatic interactions at the interface as the origin of improved PET hydrolase efficacy $(23,53)$, but the current observations suggest that even nonionic surfactants may modify the kinetics distinctively, and hence that other factors are relevant too.

\section{Conclusions}

The understanding of enzyme-catalyzed hydrolysis of PET and other plastics is not complete and there is no well-established framework for kinetic analyses of the reaction. Here, we have tested an approach to this problem, which is based on the introduction of putative attack sites on the PET surface. We showed how the number of attack sites can be readily determined experimentally and used to convert the substrate mass load into an apparent molar concentration of catalytically competent sites in the suspension. This opened up for the use of 
mass-action kinetics, and the introduction of kinetic parameters for comparative analyses. We conducted such analyses for four enzymes, and identified distinctive differences in substrate affinity, turnover rates, catalytic efficiency and the ability to locate attack sites on PET. We also demonstrated that the approach opens for kinetic comparisons of the catalytic performance on respectively intact PET and smaller (soluble or insoluble) fragments of the polymer.

Kinetics makes up the experimental link between the structure and function of catalysts (55), and we propose that the approach presented here may become a useful tool within PET hydrolase enzymology. This is both with regards to discussions of molecular mechanisms, rate limiting steps and rational design of enzymes with improved activity against this man-made substrate.

\section{Experimental procedures}

\section{Enzymes}

Two cutinases, HiC [AAE13316.1] from Humicola insolens and TfC [AAZ54921.1] from Thermobifida fusca were expressed and purified as described previously $(56,57)$. The carboxylesterase, BsCE [P37967.2] from Bacillus subtilis was expressed as secreted proteins in B. subtilis and purified as described previously (21). IsP, a Histagged variant (S238F/W159H) of the PETase from Ideonella sakaiensis [6EQD_A] was expressed as secreted proteins in B. subtilis and purified in two steps by Ni-affinity chromatography followed by gel filtration on a HiLoad 26/600 Superdex 75 pg column. The molar enzyme concentration was determined by Abs 280 and the calculated extinction coefficient (58) for the respective enzyme. The thermal transition midpoint $\left(\mathrm{T}_{\mathrm{m}}\right)$ of the enzymes was determined by differential scanning fluorimetry using a Prometeus NT.48 instrument (Nano Temper, Munich, Germany). Enzyme samples (in $50 \mathrm{mM}$ acetate buffer $\mathrm{pH}$ 5.0) with concentrations of approximately $0.5 \mathrm{mg} / \mathrm{mL}$ were heated from 20 to $95^{\circ} \mathrm{C}$ at a rate of $200^{\circ} \mathrm{C} / \mathrm{h}$.
Semi-crystalline PET powder (Product number ES306030) was purchased from Goodfellow Co (UK). The crystallinity reported by the producer was $>48 \%$. Particle sizes determined by laser diffraction ranged from 10-500 $\mu \mathrm{m}$ with a dominance of sizes around $200 \mu \mathrm{m}$ (see Fig. S1, Supporting information). Terephtalic acid (TPA), bis(2-hydroxyethyl) terephthalate (BHET) and $p$ nitrophenyl valerate ( $p \mathrm{NP}$-val), used as substrates and/or standard samples for spectrophotometric and reversed-phase high-performance liquid chromatography (RP-HPLC) analysis, were purchased from Sigma-Aldrich. Mono(2hydroxyethyl) terephthalate (MHET), used as standard sample and substrate, was produced by enzymatic hydrolysis of BHET (5 hours contact time with HiC). The oligomeric PET model substrate bis(2-(benzoyloxy)ethyl) terephthalate (BETEB) was synthesized from BHET $(25 \mathrm{~g}, 98$ mmol) and benzoyl chloride $(28.5 \mathrm{~mL}, 245 \mathrm{mmol})$ in pyridine $(100 \mathrm{~mL})$. BHET was dissolved in pyridine and cooled on ice-water. The flask was equipped with a pressure-equalizing addition funnel, magnetic stirring and nitrogen. Benzoyl chloride was added dropwise and the mixture was left stirring at room temperature overnight. Heavy precipitation made it necessary to add more pyridine $(20 \mathrm{~mL})$. For work up, DCM $(250 \mathrm{~mL})$ and ice-water $(500 \mathrm{~mL})$ was added and the mixture transferred to a separation funnel. The aqueous phase was extracted with additional DCM (200 $\mathrm{mL})$. The combined DCM-phases were washed with $0.1 \mathrm{M} \mathrm{HCl}(2 * 250 \mathrm{~mL})$ and sat. $\mathrm{NaHCO}_{3}(2$ * $200 \mathrm{~mL})$, then dried $\left(\mathrm{Na}_{2} \mathrm{SO}_{4}\right)$, filtered and evaporated. The crude product was recrystallized twice from warm anhydrous EtOH $(250 \mathrm{~mL})$. The yield was $41 \mathrm{~g}(90 \%)$ off-white solid. An overview of the chemical structures of the substrates may be found in Fig. 1. We note that PET and BETEB are essentially insoluble in buffer and investigated as stirred suspensions (see below). The other substrates, $p$ NP-val, BHET and MHET, were soluble over the concentration ranges used here. All enzyme assays were conducted in $50 \mathrm{mM}$ sodium phosphate buffer, $\mathrm{pH} 8.0$ (except the $p$ NP-val assay, see below). The PET suspension was prepared either with the addition of $0.0025 \%(\mathrm{w} / \mathrm{V})$ of the nonionic surfactant, $n$-dodecyl $\beta$-D-maltoside (DDM; Sigma-Aldrich) or without any surfactant.

\section{Substrates}




\section{Activity assay with $p$ NP-val}

Enzyme-mediated $p$-nitrophenol ( $p \mathrm{NP}$ ) release from $p$ NP-val was detected continuously over 10 $\min$ at $405 \mathrm{~nm}$. Kinetic measurements were performed in 96-well plates using a plate reader (Molecular Devices SpectraMax Paradigm). Reactions contained $150 \mu \mathrm{L} p \mathrm{NP}$-val and $30 \mu \mathrm{L}$ enzyme dissolved in $50 \mathrm{mM}$ TRIS-HCl buffer, $\mathrm{pH}$ 7.7 , with concentrations of $p \mathrm{NP}$-val ranging from 0 $0.83 \mathrm{mM}$. Measurements were performed in triplicates at $25^{\circ} \mathrm{C}$. Linear regression of a standard curve obtained with known concentrations of $p \mathrm{NP}$ was used for quantification. Data were fitted to the MM equation using ORIGIN PRO 2019 (OriginLab Coorporation, Northhampton, MA, USA).

\section{Activity assay with PET}

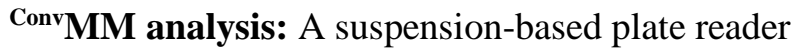
assay (33) was adapted for initial rate measurements of PET degrading enzymes. Reactions were performed in triplicates in $250 \mu \mathrm{L}$ volumes with $0.03 \mu \mathrm{M}$ enzyme and PET loads from $0-6 \mathrm{~g} / \mathrm{L}$, using low binding microplates (Greiner Bio-One ${ }^{\mathrm{TM}}$ 655900). The plates were sealed and kept at the selected temperature $\left(40{ }^{\circ} \mathrm{C}, 50{ }^{\circ} \mathrm{C}\right.$ or 60 ${ }^{\circ} \mathrm{C}$ ) in an incubator/shaker (KS 4000 ic control, operated at $450 \mathrm{rpm}$, IKA, Staufen, Germany). The contact time was 2 hours for IsP and 5 hours for HiC and TfC. These contact times were selected to get a good signal from the relatively slow enzyme reaction without exceeding the linear part of the progress curve (see Fig. S2). The reactions were stopped by centrifugation ( $3 \mathrm{~min}, 3500 \mathrm{rpm}$ ) and $100 \mu \mathrm{L}$ of supernatant was transferred to UVtransparent microplates (Corning) for spectrophotometric measurements in a plate reader at $240 \mathrm{~nm}$. Enzymatic product formation was quantified against standard curves of BHET. As described elsewhere (33) this standardization provides a reasonable measure of the overall activity. Finally, data were fitted to the MM equation using ORIGIN PRO 2019.

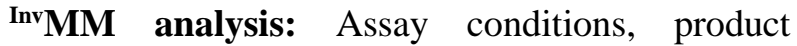
quantification and data processing for ${ }^{\text {inv }} \mathrm{MM}$ analysis were similar to the procedures for ${ }^{\text {conv }} \mathrm{MM}$ described above, except that the PET load was 10 $\mathrm{g} / \mathrm{L}$, and the enzyme concentration varied between $0-1 \mu \mathrm{M}$. The plates were kept at the experimental temperature in the incubator/shaker for 3 hours and it was confirmed that this corresponded to the linear part of the progress curve (Fig. S2).

\section{Activity assay with BETEB}

Enzyme-catalyzed BETEB hydrolysis was performed in a similar manner as the PET reactions, but analyzed by RP-HPLC due to the high background absorbance of BETEB in plate reader analysis. Samples with BETEB suspensions were incubated in an Eppendorf thermomixer at $50{ }^{\circ} \mathrm{C}$, $1100 \mathrm{rpm}$ between 10 and 40 minutes, depending on enzyme. Reactions for ${ }^{\text {conv }} \mathrm{MM}$ analysis were performed with $0.01 \mu \mathrm{M}$ enzyme and BETEB loads between 0 and $0.92 \mathrm{~g} / \mathrm{L}$. Reactions for ${ }^{\text {inv }} \mathrm{MM}$ analysis used $0.092 \mathrm{mg} / \mathrm{mL}$ BETEB and enzyme concentrations from 0 to $2 \mu \mathrm{M}$. After incubation, the samples were centrifuged and $100 \mu \mathrm{L}$ supernatant was redrawn. $\mathrm{HCl}$ was added to the supernatant and treated samples were stored in the freezer to reduce auto hydrolysis prior to RP-HPLC analysis. Enzymatically produced benzoic acid (BA, Fig. 1g) was quantified against standard curves of BA, and data were fitted to the MM equation using ORIGIN PRO 2019.

\section{Activity assay with soluble PET fragments}

Activity on the PET fragments MHET and BHET was also assayed in low binding microplates. Reactions were performed in duplicates in $250 \mu \mathrm{L}$ volumes with substrate concentrations from 0-2 $\mathrm{mM}$. Reactions were incubated in an Eppendorf thermomixer at $50{ }^{\circ} \mathrm{C}, 1100 \mathrm{rpm}$ between $10 \mathrm{~min}$ and 2 hours, depending on enzyme and substrate. Enzyme concentrations were $0.1 \mu \mathrm{M}$ (Except for HiC on BHET: $0.5 \mu \mathrm{M}$ and BsCE on BHET: 0.005 $\mu \mathrm{M})$. All reactions were stopped by addition of $\mathrm{HCl}$ and stored in the freezer prior to RP-HPLC analysis. Enzymatically produced MHET and TPA were quantified against standard curves of the same compounds, and data were fitted to the MM equation using ORIGIN PRO 2019.

\section{Reaction products detected by RP-HPLC}


The concentration of TPA, MHET and BA from selected enzyme reactions with BETEB, BHET and MHET was determined by RP-HPLC (Chemstation series 1100, Hewlett Packard). The instrument was equipped with a diode array detector and an ODSL optimal column from Capital HPLC ( 25 x 4.6 $\mathrm{mm}$ ) packed with $\mathrm{C} 18$ particles $5 \mu \mathrm{m}$ in diameter size. Injection volume was $20 \mu \mathrm{L}$ and samples were eluted with $24 \%$ acetonitrile over 25 minutes. Products were identified based on absorption at 240 $\mathrm{nm}$. Flow rate was set to $0.5 \mathrm{~mL} / \mathrm{min}$ and the column was kept at $40{ }^{\circ} \mathrm{C}$. Peak analysis was performed using the ChemStation for LC 3D software. Standards with known concentrations of TPA, MHET, BHET and BA were used to quantify reaction products for kinetic analyses. Duplicates and substrate blanks (for quantification of auto hydrolysis) were included for all reactions.

Data availability: All data that support the findings of this study are included in the published article and its Supporting information file. 


\section{Acknowledgements}

We would like to thank Anni Bygvrå Hougaard and Linda Rikke Dietrich, University of Copenhagen and Claus Sternberg, DTU-Bioengineering's Bioimaging Platform for assistance in the characterization of PET particle size.

\section{Funding}

This work was supported by the Novo Nordisk foundation Grant NNFSA170028392 (to P. W.).

Conflict of Interest: K.B., K.J. and J.B. work for Novozymes A/S, a major manufacturer of industrial enzymes.

\section{References}

1. Hiraga, K., Taniguchi, I., Yoshida, S., Kimura, Y., and Oda, K. (2019) Biodegradation of waste PET: A sustainable solution for dealing with plastic pollution. EMBO Rep. 10.15252/embr.201949365

2. Danso, D., Chow, J., and Streita, W. R. (2019) Plastics: Environmental and biotechnological perspectives on microbial degradation. Appl. Environ. Microbiol. 85, 1-14

3. Kawai, F., Kawabata, T., and Oda, M. (2019) Current knowledge on enzymatic PET degradation and its possible application to waste stream management and other fields. Appl. Microbiol. Biotechnol. 103, 4253-4268

4. Tournier, V., Topham, C. M., Gilles, A., David, B., Folgoas, C., Moya-Leclair, E., Kamionka, E., Desrousseaux, M. L., Texier, H., Gavalda, S., Cot, M., Guémard, E., Dalibey, M., Nomme, J., Cioci, G., Barbe, S., Chateau, M., André, I., Duquesne, S., and Marty, A. (2020) An engineered PET depolymerase to break down and recycle plastic bottles. Nature. 580, 216-219

5. Nikolaivits, E., Kanelli, M., Dimarogona, M., and Topakas, E. (2018) A middle-aged enzyme still in its prime: Recent advances in the field of cutinases. Catalysts. 10.3390/catal8120612

6. Chen, S., Su, L., Chen, J., and Wu, J. (2013) Cutinase: Characteristics, preparation, and application. Biotechnol. Adv. 31, 1754-1767

7. Wei, R., and Zimmermann, W. (2017) Microbial enzymes for the recycling of recalcitrant petroleum-based plastics: how far are we? Microb. Biotechnol. 10, 1308-1322

8. Ronkvist, Å. M., Xie, W., Lu, W., and Gross, R. A. (2009) Cutinase-Catalyzed hydrolysis of poly(ethylene terephthalate). Macromolecules. 42, 5128-5138

9. Han, X., Liu, W., Huang, J. W., Ma, J., Zheng, Y., Ko, T. P., Xu, L., Cheng, Y. S., Chen, C. C., and Guo, R. T. (2017) Structural insight into catalytic mechanism of PET hydrolase. Nat. Commun. 10.1038/s41467-017-02255-Z

10. Joo, S., Cho, I. J., Seo, H., Son, H. F., Sagong, H. Y., Shin, T. J., Choi, S. Y., Lee, S. Y., and Kim, K. J. (2018) Structural insight into molecular mechanism of poly(ethylene terephthalate) degradation. Nat. Commun. 10.1038/s41467-018-02881-1

11. Fecker, T., Galaz-Davison, P., Engelberger, F., Narui, Y., Sotomayor, M., Parra, L. P., and 
Ramírez-Sarmiento, C. A. (2018) Active Site Flexibility as a Hallmark for Efficient PET Degradation by I. sakaiensis PETase. Biophys. J. 114, 1302-1312

12. Austin, H. P., Allen, M. D., Donohoe, B. S., Rorrer, N. A., Kearns, F. L., Silveira, R. L., Pollard, B. C., Dominick, G., Duman, R., Omari, K. El, Mykhaylyk, V., Wagner, A., Michener, W. E., Amore, A., Skaf, M. S., Crowley, M. F., Thorne, A. W., Johnson, C. W., Lee Woodcock, H., McGeehan, J. E., and Beckham, G. T. (2018) Characterization and engineering of a plasticdegrading aromatic polyesterase. Proc. Natl. Acad. Sci. U. S. A. 115, E4350-E4357

13. Barth, M., Oeser, T., Wei, R., Then, J., Schmidt, J., and Zimmermann, W. (2015) Effect of hydrolysis products on the enzymatic degradation of polyethylene terephthalate nanoparticles by a polyester hydrolase from Thermobifida fusca. Biochem. Eng. J. 93, 222-228

14. Silva, C., Da, S., Silva, N., Matamá, T., Araújo, R., Martins, M., Chen, S., Chen, J., Wu, J., Casal, M., and Cavaco-Paulo, A. (2011) Engineered Thermobifida fusca cutinase with increased activity on polyester substrates. Biotechnol. J. 6, 1230-1239

15. Wei, R., Oeser, T., Schmidt, J., Meier, R., Barth, M., Then, J., and Zimmermann, W. (2016) Engineered bacterial polyester hydrolases efficiently degrade polyethylene terephthalate due to relieved product inhibition. Biotechnol. Bioeng. 113, 1658-1665

16. Belisário-Ferrari, M. R., Wei, R., Schneider, T., Honak, A., and Zimmermann, W. (2019) Fast Turbidimetric Assay for Analyzing the Enzymatic Hydrolysis of Polyethylene Terephthalate Model Substrates. Biotechnol. J. 14, 10-14

17. Shirke, A. N., White, C., Englaender, J. A., Zwarycz, A., Butterfoss, G. L., Linhardt, R. J., and Gross, R. A. (2018) Stabilizing Leaf and Branch Compost Cutinase (LCC) with Glycosylation: Mechanism and Effect on PET Hydrolysis. Biochemistry. 57, 1190-1200

18. Son, H. F., Cho, I. J., Joo, S., Seo, H., Sagong, H. Y., Choi, S. Y., Lee, S. Y., and Kim, K. J. (2019) Rational Protein Engineering of Thermo-Stable PETase from Ideonella sakaiensis for Highly Efficient PET Degradation. ACS Catal. 9, 3519-3526

19. Araújo, R., Silva, C., O’Neill, A., Micaelo, N., Guebitz, G., Soares, C. M., Casal, M., and CavacoPaulo, A. (2007) Tailoring cutinase activity towards polyethylene terephthalate and polyamide 6,6 fibers. J. Biotechnol. 128, 849-857

20. Sulaiman, S., Yamato, S., Kanaya, E., Kim, J. J., Koga, Y., Takano, K., and Kanaya, S. (2012) Isolation of a novel cutinase homolog with polyethylene terephthalate-degrading activity from leaf-branch compost by using a metagenomic approach. Appl. Environ. Microbiol. 78, 1556-1562

21. Ribitsch, D., Heumann, S., Trotscha, E., Herrero Acero, E., Greimel, K., Leber, R., BirnerGruenberger, R., Deller, S., Eiteljoerg, I., Remler, P., Weber, T., Siegert, P., Maurer, K. H., Donelli, I., Freddi, G., Schwab, H., and Guebitz, G. M. (2011) Hydrolysis of polyethyleneterephthalate by p-nitrobenzylesterase from Bacillus subtilis. Biotechnol. Prog. 27, 951-960

22. Müller, R. J., Schrader, H., Profe, J., Dresler, K., and Deckwer, W. D. (2005) Enzymatic degradation of poly(ethylene terephthalate): Rapid hydrolyse using a hydrolase from T. fusca. Macromol. Rapid Commun. 26, 1400-1405

23. Furukawa, M., Kawakami, N., Oda, K., and Miyamoto, K. (2018) Acceleration of Enzymatic Degradation of Poly(ethylene terephthalate) by Surface Coating with Anionic Surfactants. ChemSusChem. 11, 4018-4025

24. Bansal, P., Hall, M., Realff, M. J., Lee, J. H., and Bommarius, A. S. (2009) Modeling cellulase 
kinetics on lignocellulosic substrates. Biotechnol. Adv. 27, 833-848

25. Dumesic, J. A., Rudd, D. F., Aparicio, L. M., Rekoske, J. E., and Treviño, A. A. (1993) The Microkinetics of Heterogeneous Catalysis, Am Chem Soc, Washington, DC

26. Beller, M., Renken, A., and van Santen, R. A. (2012) Catalysis: From Principles to Applications, Wiley-VCH, Weinheim

27. Kari, J., Andersen, M., Borch, K., and Westh, P. (2017) An Inverse Michaelis-Menten Approach for Interfacial Enzyme Kinetics. ACS Catal. 7, 4904-4914

28. Scandola, M., Focarete, M. L., and Frisoni, G. (1998) Simple kinetic model for the heterogeneous enzymatic hydrolysis of natural poly(3-hydroxybutyrate). Macromolecules. 31, 3846-3851

29. Andersen, M., Kari, J., Borch, K., and Westh, P. (2018) Michaelis-Menten equation for degradation of insoluble substrate. Math. Biosci. 296, 93-97

30. McLaren, A. D., and Packer, L. (1970) Some Aspects of Enzyme Reactions in Heterogeneous Systems. Adv. Enzymol. Relat. Areas Mol. Biol. doi:10.1002/9780470122785.ch5

31. Moorhead, D. L., and Weintraub, M. N. (2018) The evolution and application of the reverse Michaelis-Menten equation. Soil Biol. Biochem. 125, 261-262

32. Bailey, C. J. (1989) Enzyme kinetics of cellulose hydrolysis. Biochem. J. 262, 1001-1001

33. Arnling Bååth, J., Borch, K., and Westh, P. (2020) A suspension-based assay and comparative detection methods for characterization of polyethylene terephthalate hydrolases. Anal. Biochem. 607, 113873

34. Mukai, K., Yamada, K., and Doi, Y. (1993) Kinetics and mechanism of heterogeneous hydrolysis of poly[(R)-3-hydroxybutyrate] film by PHA depolymerases. Int. J. Biol. Macromol. 15, 361-366

35. Hiraishi, T., Komiya, N., Matsumoto, N., Abe, H., Fujita, M., and Maeda, M. (2010) Degradation and adsorption characteristics of PHB depolymerase as revealed by kinetics of mutant enzymes with amino acid substitution in substrate-binding domain. Biomacromolecules. 11, 113-119

36. Timmins, M. R., Lenz, R. W., and Fuller, R. C. (1997) Heterogeneous kinetics of the enzymatic degradation of poly( $\beta$-hydroxyalkanoates). Polymer (Guildf). 38, 551-562

37. Sharma, S., Berne, B. J., and Kumar, S. K. (2010) Thermal and structural stability of adsorbed proteins. Biophys. J. 99, 1157-1165

38. Yoshida, S., Hiraga, K., Takehana, T., Taniguchi, I., Yamaji, H., Maeda, Y., Toyohara, K., Miyamoto, K., Kimura, Y., and Oda, K. (2016) A bacterium that degrades and assimilates poly(ethylene terephthalate). Science. 351, 1196-1199

39. Liu, B., He, L., Wang, L., Li, T., Li, C., Liu, H., Luo, Y., and Bao, R. (2018) Protein crystallography and site-direct mutagenesis analysis of the poly(Ethylene terephthalate) hydrolase petase from Ideonella sakaiensis. ChemBioChem. 19, 1471-1475

40. Sousa, S. F., Ramos, M. J., Lim, C., and Fernandes, P. A. (2015) Relationship between Enzyme/Substrate Properties and Enzyme Efficiency in Hydrolases. ACS Catal. 5, 5877-5887

41. Bar-Even, A., Noor, E., Savir, Y., Liebermeister, W., Davidi, D., Tawfik, D. S., and Milo, R. (2011) The moderately efficient enzyme: Evolutionary and physicochemical trends shaping enzyme parameters. Biochemistry. 50, 4402-4410 
42. Davidi, D., Longo, L. M., Jabłońska, J., Milo, R., and Tawfik, D. S. (2018) A Bird's-Eye View of Enzyme Evolution: Chemical, Physicochemical, and Physiological Considerations. Chem. Rev. 118, 8786-8797

43. Payne, C. M., Himmel, M. E., Crowley, M. F., and Beckham, G. T. (2011) Decrystallization of oligosaccharides from the cellulose I $\beta$ surface with molecular simulation. J. Phys. Chem. Lett. 2, $1546-1550$

44. Sørensen, T. H., Cruys-Bagger, N., Borch, K., and Westh, P. (2015) Free energy diagram for the heterogeneous enzymatic hydrolysis of glycosidic bonds in cellulose. J. Biol. Chem. 290, 2220322211

45. Wackett, L. P., and Robinson, S. L. (2020) The ever-expanding limits of enzyme catalysis and biodegradation: polyaromatic, polychlorinated, polyfluorinated, and polymeric compounds. Biochem. J. 477, 2875-2891

46. Baptista, R. P., Santos, A. M., Fedorov, A., Martinho, J. M. G., Pichot, C., Elaïssari, A., Cabral, J. M. S., and Taipa, M. A. (2003) Activity, conformation and dynamics of cutinase adsorbed on poly(methyl methacrylate) latex particles. J. Biotechnol. 102, 241-249

47. Zoungrana, T., Findenegg, G. H., and Norde, W. (1997) Structure, Stability, and Activity of Adsorbed Enzymes. J. Colloid Interface Sci. 190, 437-448

48. Christensen, S. J., Kari, J., Badino, S. F., Borch, K., and Westh, P. (2018) Rate-limiting step and substrate accessibility of cellobiohydrolase Cel6A from Trichoderma reesei. FEBS J. 285, 44824493

49. Schiano-di-Cola, C., Røjel, N., Jensen, K., Kari, J., Sørensen, T. H., Borch, K., and Westh, P. (2019) Systematic deletions in the cellobiohydrolase (CBH) Cel7A from the fungus Trichoderma reesei reveal flexible loops critical for CBH activity. J. Biol. Chem. 294, 1807-1815

50. Weber, J., Petrović, D., Strodel, B., Smits, S. H. J., Kolkenbrock, S., Leggewie, C., and Jaeger, K. E. (2019) Interaction of carbohydrate-binding modules with poly(ethylene terephthalate). Appl. Microbiol. Biotechnol. 103, 4801-4812

51. Ribitsch, D., Yebra, A. O., Zitzenbacher, S., Wu, J., Nowitsch, S., Steinkellner, G., Greimel, K., Doliska, A., Oberdorfer, G., Gruber, C. C., Gruber, K., Schwab, H., Stana-Kleinschek, K., Acero, E. H., and Guebitz, G. M. (2013) Fusion of binding domains to Thermobifida cellulosilytica cutinase to tune sorption characteristics and enhancing PET hydrolysis. Biomacromolecules. 14, 1769-1776

52. Gao, A., Shen, H., Zhang, H., Feng, G., and Xie, K. (2017) Hydrophilic modification of polyester fabric by synergetic effect of biological enzymolysis and non-ionic surfactant, and applications in cleaner production. J. Clean. Prod. 164, 277-287

53. Furukawa, M., Kawakami, N., Tomizawa, A., and Miyamoto, K. (2019) Efficient Degradation of Poly(ethylene terephthalate) with Thermobifida fusca Cutinase Exhibiting Improved Catalytic Activity Generated using Mutagenesis and Additive-based Approaches. Sci. Rep. 9, 1-9

54. Gamerith, C., Vastano, M., Ghorbanpour, S. M., Zitzenbacher, S., Ribitsch, D., Zumstein, M. T., Sander, M., Acero, E. H., Pellis, A., and Guebitz, G. M. (2017) Enzymatic degradation of aromatic and aliphatic polyesters by P. pastoris expressed cutinase 1 from Thermobifida cellulosilytica. Front. Microbiol. 8, 1-14

55. Nørskov, J. K., Bligaard, T., Rossmeisl, J., and Christensen, C. H. (2009) Towards the computational design of solid catalysts. Nat. Chem. 1, 37-46 
56. Sandal, T., Kauppinen, S., and Venke Kofod, L. (1998) Enzyme with lipolytic activity

57. Adams, C., and Schmidt, B. (2011) Detergent compositions containing Thermobifida fusca lipase and methods of use thereof

58. Gasteiger, E., Hoogland, C., Gattiker, A., Duvaud, S., Wilkins, M. R., Appel, R. D., and Bairoch, A. (2005) The Proteomics Protocols Handbook. Proteomics Protoc. Handb. 10.1385/1592598900

Abbreviations: BA, Benzoic acid; BETEB, Bis(2-(benzoyloxy)ethyl) terephthalate; BHET, Bis(2hydroxyethyl) terephthalate; DDM, n-Dodecyl $\beta$-D-maltoside; EG, Ethylene glycol; $\Gamma_{\text {attack }}$, density of attack sites; MHET, Mono(2-hydroxyethyl) terephthalate; MM, Michaelis-Menten; PET, Poly(ethylene terephthalate); $p$ NP-val, $p$-Nitrophenyl valerate; RP-HPLC, Reversed-phase high-performance liquid chromatography; TPA, Terephthalic acid. 
Table 1. ${ }^{\text {Conv }} \mathrm{MM}$ parameters determined for $\mathrm{HiC}$, TfC and IsP on PET at 40,50 or $60{ }^{\circ} \mathrm{C}$ with or without the addition of the nonionic surfactant DDM. It was not possible to resolve ${ }^{\text {conv }} \mathrm{K}_{\mathrm{M}}$ and $\mathrm{k}_{\text {cat }}$ from reactions at $40{ }^{\circ} \mathrm{C}$ with DDM for any of the enzymes. Numbers in brackets represent standard deviations of triplicate measurements.

\begin{tabular}{|c|c|c|c|c|c|c|}
\hline $\begin{array}{c}\mathrm{T}\left({ }^{\circ} \mathrm{C}\right) / \\
\text { Surfactant }\end{array}$ & $\begin{array}{l}\text { HiC } \\
{ }^{c o n v} K_{M} \\
\left(g L^{-1}\right)\end{array}$ & $\begin{array}{l}k_{c a t}={ }^{c o n v} V_{\max } / E_{0} \\
\left(s^{-1}\right)\end{array}$ & $\begin{array}{l}\text { TfC } \\
{ }^{c o n v} K_{M} \\
\left(g L^{-1}\right)\end{array}$ & $\begin{array}{l}k_{c a t}={ }^{c o n v} V_{\max } / E_{0} \\
\left(s^{-1}\right)\end{array}$ & $\begin{array}{l}\text { IsP } \\
{ }^{c o n v} K_{M} \\
\left(g L^{-1}\right)\end{array}$ & $\begin{array}{l}k_{c a t}={ }^{c o n v} V_{\max } / E_{0} \\
\left(s^{-1}\right)\end{array}$ \\
\hline $40 /$ no & ND* & ND & ND & ND & $\begin{array}{l}\mathbf{4 . 9} \\
( \pm 0.90)\end{array}$ & $\begin{array}{l}\mathbf{0 . 5 2} \\
( \pm 0.053)\end{array}$ \\
\hline 50/no & $\begin{array}{l}\mathbf{0 . 2 7} \\
( \pm 0.039)\end{array}$ & $\begin{array}{l}\mathbf{0 . 0 8 8} \\
( \pm 0.0021)\end{array}$ & $\begin{array}{l}\mathbf{1 . 2} \\
( \pm 1.1)\end{array}$ & $\begin{array}{l}\mathbf{0 . 0 1 5} \\
( \pm 0.0059)\end{array}$ & $\begin{array}{l}\mathbf{0 . 2 4} \\
( \pm 0.058)\end{array}$ & $\begin{array}{l}\mathbf{0 . 6 9} \\
( \pm 0.031)\end{array}$ \\
\hline $60 /$ no & $\begin{array}{l}\mathbf{0 . 2 6} \\
( \pm 0.16)\end{array}$ & $\begin{array}{l}\mathbf{0 . 0 4 3} \\
( \pm 0.0051)\end{array}$ & $\begin{array}{l}\mathbf{0 . 6 8} \\
( \pm 0.014)\end{array}$ & $\begin{array}{l}\mathbf{0 . 0 5 2} \\
( \pm 0.0034)\end{array}$ & ND & ND \\
\hline $50 / \mathrm{DDM}$ & $\begin{array}{l}\mathbf{4 . 0} \\
( \pm 2.4)\end{array}$ & $\begin{array}{l}\mathbf{0 . 2 0} \\
( \pm 0.07)\end{array}$ & $\begin{array}{l}\mathbf{3 . 4} \\
( \pm 1.7)\end{array}$ & $\begin{array}{l}\mathbf{0 . 0 9 1} \\
( \pm 0.024)\end{array}$ & $\begin{array}{l}\mathbf{2 . 2} \\
( \pm 0.37)\end{array}$ & $\begin{array}{l}\mathbf{1 . 8} \\
( \pm 0.14)\end{array}$ \\
\hline 60/DDM & $\begin{array}{l}4.7 \\
( \pm 3.0)\end{array}$ & $\begin{array}{l}\mathbf{0 . 1 2} \\
( \pm 0.043)\end{array}$ & $\begin{array}{l}1.2 \\
( \pm 0.65)\end{array}$ & $\begin{array}{l}\mathbf{0 . 0 8 1} \\
( \pm 0.015)\end{array}$ & ND & ND \\
\hline
\end{tabular}

*ND: Not determined. Either due to experimental temperature above $\mathrm{T}_{\mathrm{m}}$ of the enzyme (IsP, $\left.60{ }^{\circ} \mathrm{C}\right)$ or activity below experimental detection limit ( $\mathrm{HiC}$ and $\mathrm{TfC}$ at $\left.40{ }^{\circ} \mathrm{C}\right)$. 
Table 2. ${ }^{\text {Inv }} \mathrm{MM}$ parameters determined for $\mathrm{HiC}$, TfC and IsP on PET at 40,50 or $60{ }^{\circ} \mathrm{C}$ with or without the addition of the nonionic surfactant DDM. The parameters calculated for IsP are based on an approximated fitting of the data (see Fig. 4). Numbers in brackets represent standard deviations of triplicate measurements.

\begin{tabular}{|c|c|c|c|c|c|c|}
\hline $\begin{array}{c}\mathrm{T}\left({ }^{\circ} \mathrm{C}\right) / \\
\text { Surfactant }\end{array}$ & $\begin{array}{c}\mathbf{H i C} \\
{ }^{i n v} K_{M} \\
(\mu M)\end{array}$ & $\begin{array}{l}{ }^{i n v} V_{\max } / S_{0} \\
(\mu \mathrm{molg}-1 \\
\left.\mathrm{s}^{-1}\right)\end{array}$ & $\begin{array}{c}{ }_{\text {TfC }} \\
{ }^{i n} K_{M} \\
(\mu M)\end{array}$ & $\begin{array}{l}{ }^{i n v} V_{\max } / S_{0} \\
\left(\mu \operatorname{molg}{ }^{-1} s^{-1}\right)\end{array}$ & $\begin{array}{l}\text { IsP } \\
{ }^{i n v} K_{M} \\
(\mu M)\end{array}$ & $\begin{array}{l}{ }^{i n v} V_{\max } / S_{0} \\
(\mu \mathrm{molg}-1 \\
\left(\mu s^{-1}\right)\end{array}$ \\
\hline 40/no & ND* & ND & ND & ND & $\begin{array}{l}\mathbf{0 . 0 3 9} \\
( \pm 0.017)\end{array}$ & $\begin{array}{l}\mathbf{0 . 0 0 2 6} \\
( \pm 3.5 \mathrm{E}-4)\end{array}$ \\
\hline $50 /$ no & $\begin{array}{l}\mathbf{0 . 0 4 3} \\
( \pm 0.012)\end{array}$ & $\begin{array}{l}\mathbf{0 . 0 0 1 1} \\
( \pm 7.6 \mathrm{E}-5)\end{array}$ & $\begin{array}{l}\mathbf{0 . 0 2 6} \\
( \pm 0.0067)\end{array}$ & $\begin{array}{l}\mathbf{0 . 0 0 0 5 3} \\
( \pm 2.5 \mathrm{E}-5)\end{array}$ & ND & ND \\
\hline $60 /$ no & $\begin{array}{l}\mathbf{0 . 2 8} \\
( \pm 0.074)\end{array}$ & $\begin{array}{l}\mathbf{0 . 0 0 5 7} \\
( \pm 6.0 \mathrm{E}-4)\end{array}$ & $\begin{array}{l}\mathbf{0 . 2 0} \\
( \pm 0.019)\end{array}$ & $\begin{array}{l}\mathbf{0 . 0 0 7 8} \\
( \pm 2.7 \mathrm{E}-4)\end{array}$ & ND & ND \\
\hline 40/DDM & ND & ND & ND & ND & $\begin{array}{l}\mathbf{0 . 1 1} \\
( \pm 0.038)\end{array}$ & $\begin{array}{l}\mathbf{0 . 0 0 7 8} \\
( \pm 0.0013)\end{array}$ \\
\hline 50/DDM & $\begin{array}{l}\mathbf{0 . 0 9 0} \\
( \pm 0.038)\end{array}$ & $\begin{array}{l}\mathbf{0 . 0 0 1 8} \\
( \pm 2.1 \mathrm{E}-4)\end{array}$ & $\begin{array}{l}\mathbf{0 . 1 1} \\
( \pm 0.026)\end{array}$ & $\begin{array}{l}\mathbf{0 . 0 0 0 8 6} \\
( \pm 7.8 \mathrm{E}-5)\end{array}$ & ND & ND \\
\hline 60/DDM & $\begin{array}{l}\mathbf{0 . 1 6} \\
( \pm 0.052)\end{array}$ & $\begin{array}{l}\mathbf{0 . 0 0 5 3} \\
( \pm 5.9 \mathrm{E}-4)\end{array}$ & $\begin{array}{l}\mathbf{0 . 3 1} \\
( \pm 0.025)\end{array}$ & $\begin{array}{l}\mathbf{0 . 0 0 6 5} \\
( \pm 2.2 \mathrm{E}-4)\end{array}$ & ND & ND \\
\hline
\end{tabular}

*ND: Not determined. Either not possible to fit data to the MM equation (IsP, $50{ }^{\circ} \mathrm{C}$ ), experimental temperature above $\mathrm{T}_{\mathrm{m}}$ of the enzyme (IsP, $60^{\circ} \mathrm{C}$ ) or activity below experimental detection limit ( $\mathrm{HiC}$ and $\mathrm{TfC}$ at $\left.40^{\circ} \mathrm{C}\right)$. 
Table 3. The specificity constant $\left({ }^{\text {mass }} \eta\right)$ and the attack site density $\left(\Gamma_{\text {attack }}\right)$ for PET hydrolase reactions at 40, 50 and $60{ }^{\circ} \mathrm{C}$ with or without the addition of the surfactant DDM. $\Gamma_{\text {attack }}$ is not reported for IsP due to the uncertain inverse maximal specific rates (see Table 2 and Fig. 4). Numbers in brackets represent standard deviations of triplicate measurements.

\begin{tabular}{|c|c|c|c|c|c|}
\hline \multirow{2}{*}{$\begin{array}{l}\mathrm{T}\left({ }^{\circ} \mathrm{C}\right) / \\
\text { Surfactant }\end{array}$} & \multicolumn{3}{|c|}{${ }_{\text {mass }} \eta\left(\operatorname{Lg}^{-1} \mathrm{~s}^{-1}\right)$} & \multicolumn{2}{|c|}{$\boldsymbol{\Gamma}_{\text {attack }}(\mu \mathrm{mol} / \mathrm{g})$} \\
\hline & $\mathrm{HiC}$ & $\mathrm{TfC}$ & IsP & $\mathrm{HiC}$ & $\mathrm{TfC}$ \\
\hline & ND* & ND & $\begin{array}{l}\mathbf{0 . 1 1} \\
( \pm 0.022)\end{array}$ & ND & ND \\
\hline $50 /$ no & $\begin{array}{l}\mathbf{0 . 3 3} \\
( \pm 0.048)\end{array}$ & $\begin{array}{l}\mathbf{0 . 0 1 3} \\
( \pm 0.013)\end{array}$ & $\begin{array}{l}\mathbf{2 . 9} \\
( \pm 0.71)\end{array}$ & $\begin{array}{l}\mathbf{0 . 0 1 3} \\
( \pm 0.018)\end{array}$ & $\begin{array}{l}\mathbf{0 . 0 3 5} \\
( \pm 0.014)\end{array}$ \\
\hline $60 /$ no & $\begin{array}{l}\mathbf{0 . 1 7} \\
( \pm 0.10)\end{array}$ & $\begin{array}{l}\mathbf{0 . 0 7 6} \\
( \pm 0.017)\end{array}$ & ND & $\begin{array}{l}\mathbf{0 . 1 3} \\
( \pm 0.090)\end{array}$ & $\begin{array}{l}\mathbf{0 . 1 5} \\
( \pm 0.019)\end{array}$ \\
\hline 40/DDM & ND & ND & $\begin{array}{l}\mathbf{0 . 0 7 5} \\
( \pm 0.024)\end{array}$ & ND & ND \\
\hline 50/DDM & $\begin{array}{l}\mathbf{0 . 0 5 0} \\
( \pm 0.035)\end{array}$ & $\begin{array}{l}\mathbf{0 . 0 2 7} \\
( \pm 0.015)\end{array}$ & $\begin{array}{l}\mathbf{0 . 8 2} * * \\
( \pm 0.15)\end{array}$ & $\begin{array}{l}\mathbf{0 . 0 0 9 0} \\
( \pm 0.0033)\end{array}$ & $\begin{array}{l}\mathbf{0 . 0 0 9 5} \\
( \pm 0.0026)\end{array}$ \\
\hline 60/DDM & $\begin{array}{l}\mathbf{0 . 0 2 6} \\
( \pm 0.019)\end{array}$ & $\begin{array}{l}\mathbf{0 . 0 6 8} \\
( \pm 0.039)\end{array}$ & ND & $\begin{array}{l}\mathbf{0 . 0 4 4} \\
( \pm 0.017)\end{array}$ & $\begin{array}{l}\mathbf{0 . 0 8 0} \\
( \pm 0.015)\end{array}$ \\
\hline
\end{tabular}

*ND: Not determined. Either due to experimental temperature above $\mathrm{T}_{\mathrm{m}}$ of the enzyme (IsP, $\left.60{ }^{\circ} \mathrm{C}\right)$ or activity below experimental detection limit ( $\mathrm{HiC}$ and $\mathrm{TfC}$ at $40^{\circ} \mathrm{C}$ ).

***Determined by linear fit, since not possible to extract the ${ }^{\text {conv }} \mathrm{MM}$ parameters $\mathrm{k}_{\mathrm{cat}}$ and $\mathrm{K}_{\mathrm{M}}$ from these data. 
Table 4. Kinetic parameters including $\Gamma_{\text {attack }}$ and ${ }^{\text {mass }} \eta$ from conventional and inverse $M M$ analyses on BETEB at $50{ }^{\circ} \mathrm{C}$, calculated from the data in Fig. 5. Numbers in brackets represent standard deviations of duplicate measurements.

\begin{tabular}{lllllll}
\hline Enzyme & $\begin{array}{l}\text { conv }_{\mathbf{M}} \\
\left(\mathrm{gL}^{-1}\right)\end{array}$ & $\begin{array}{l}{ }^{\text {conv }} \mathbf{V}_{\text {max }} / \mathbf{E}_{\mathbf{0}} \\
\left(\mathrm{s}^{-1}\right)\end{array}$ & $\begin{array}{l}{ }^{\text {inv }} \mathbf{K}_{\mathbf{M}} \\
(\mu \mathrm{M})\end{array}$ & $\begin{array}{l}{ }^{\text {inv }} \mathbf{V}_{\text {max }} / \mathbf{S}_{\mathbf{0}} \\
\left(\mu \mathrm{molg} \mathrm{s}^{-1}\right)\end{array}$ & $\begin{array}{l}\boldsymbol{\Gamma}_{\text {attack }} \\
(\mu \mathrm{mol} / \mathrm{g})\end{array}$ & $\begin{array}{l}\text { mass } \\
\left(\mathrm{Lg}^{-1} \mathrm{~s}^{-1}\right)\end{array}$ \\
\hline $\mathrm{HiC}$ & $\mathbf{0 . 2 5}$ & $\mathbf{2 . 0 8}$ & $\mathbf{0 . 4 3}$ & $\mathbf{5 . 7}$ & $\mathbf{2 . 7}$ & $\mathbf{8 . 3}$ \\
& $( \pm 0.021)$ & $( \pm 0.071)$ & $( \pm 0.064)$ & $( \pm 0.32)$ & $( \pm 0.18)$ & $( \pm 0.75)$ \\
$\mathrm{TfC}$ & $\mathbf{0 . 1 6}$ & $\mathbf{2 . 3 8}$ & $\mathbf{0 . 2 3}$ & $\mathbf{2 . 1 5}$ & $\mathbf{0 . 9 0}$ & $\mathbf{1 5}$ \\
& $( \pm 0.019)$ & $( \pm 0.097)$ & $( \pm 0.045)$ & $( \pm 0.20)$ & $( \pm 0.15)$ & $( \pm 1.9)$ \\
$\mathrm{IsP}$ & $\mathbf{0 . 1 4}$ & $\mathbf{5 . 2 5}$ & $\mathbf{0 . 1 7}$ & $\mathbf{3 . 4 2}$ & $\mathbf{0 . 6 5}$ & $\mathbf{3 8}$ \\
& $( \pm 0.029)$ & $( \pm 0.43)$ & $( \pm 0.012)$ & $( \pm 0.098)$ & $( \pm 0.057)$ & $( \pm 8.4)$ \\
BsCE & ND* & $\mathbf{N D}$ & $\mathbf{0 . 0 9 5}$ & $\mathbf{0 . 1 5}$ & $\mathbf{N D}$ & $\mathbf{N D}$ \\
& & & $( \pm 0.023)$ & $( \pm 0.012)$ & & \\
\hline
\end{tabular}

*ND: Not determined, activities below experimental detection limit 
Table 5. Specificity constants at $50{ }^{\circ} \mathrm{C}$ determined for $\mathrm{HiC}$, TfC, IsP and $\mathrm{BsCE}$ on soluble substrates, including the PET fragments MHET and BHET as well as the model substrate $p$ NP-val. Standard deviations of duplicate or triplicate measurements are shown in brackets. The underlying values of $\mathrm{k}_{\text {cat }}$ and $\mathrm{K}_{\mathrm{M}}$ may be found in Table S1 of the Supporting information.

\begin{tabular}{lllll}
\hline \multirow{2}{*}{ Substrate/Enzyme } & $\eta\left(\mathrm{M}^{-1} \mathrm{~s}^{-1}\right)$ & & & \\
\cline { 2 - 5 } & $\mathrm{HiC}$ & $\mathrm{TfC}$ & $\mathrm{IsP}$ & $\mathrm{BsCE}$ \\
\hline$p$ NP-val & $\mathbf{1 . 9 0 \times 1 0 ^ { \mathbf { 5 } }}$ & $\mathbf{2 . 3 \times 1 0 ^ { 4 }}$ & $\mathbf{4 . 4 \times 1 0 ^ { 3 }}$ & $\mathbf{1 . 9 \times 1 0 ^ { 4 }}$ \\
& $\left( \pm 3.1 \times 10^{4}\right)$ & $\left( \pm 3.6 \times 10^{4}\right)$ & $\left( \pm 1.2 \times 10^{3}\right)$ & $\left( \pm 2.1 \times 10^{3}\right)$ \\
MHET & $\mathrm{ND}^{*}$ & $\mathbf{1 3}$ & $\mathrm{ND}$ & $\mathbf{4 5}$ \\
& & $( \pm 1.1)$ & & $( \pm 22)$ \\
BHET & $\mathbf{5 . 5 x 1 0}^{\mathbf{2}}$ & $\mathbf{1 . 9 \times 1 0 ^ { 3 }}$ & $\mathbf{3 . 3 \times 1 0 ^ { 3 }}$ & $\mathbf{1 . 7 \times 1 0 ^ { 4 }}$ \\
& $( \pm 44)$ & $\left( \pm 0.76 \times 10^{3}\right)$ & $\left( \pm 2.1 \times 10^{2}\right)$ & $\left( \pm 2.1 \times 10^{3}\right)$ \\
\hline
\end{tabular}

*ND: Not determined, activities below the experimental detection limit. 
Table 6. Molar specificity constants ( ${ }^{\text {molar }} \eta$ ) calculated according to eq. (8) for HiC, TfC and IsP acting on the insoluble substrates PET and BETEB at $50{ }^{\circ} \mathrm{C}$ (without the addition of DDM).

\begin{tabular}{llll}
\hline $\mathrm{T}\left({ }^{\circ} \mathrm{C}\right)$ & HiC $\left(\mathrm{M}^{-1} \mathrm{~s}^{-1}\right)$ & TfC $\left(\mathrm{M}^{-1} \mathrm{~s}^{-1}\right)$ & IsP $\left(\mathrm{M}^{-1} \mathrm{~s}^{-1}\right)$ \\
\hline BETEB & $\mathbf{3 . 9 \times 1 0 ^ { 3 }}$ & $\mathbf{6 . 8 \times 1 0}$ & $\mathbf{1 . 7 \times 1 0 ^ { 4 }}$ \\
PET & $\mathbf{2 . 5 \times 1 0 ^ { 7 }}$ & $\mathbf{3 . 6 x 1 0}^{\mathbf{7}}$ & $>\mathbf{1 0}^{6} *$
\end{tabular}

*Estimation based on the highest directly measured rate in Fig. 4. 


\section{Figures}

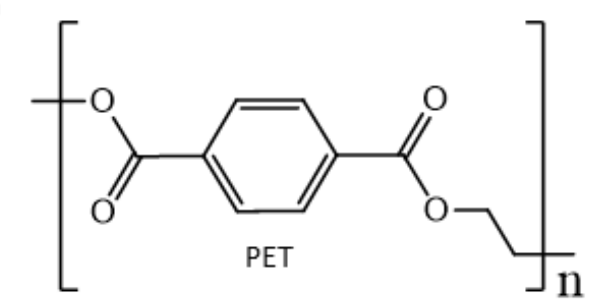

b
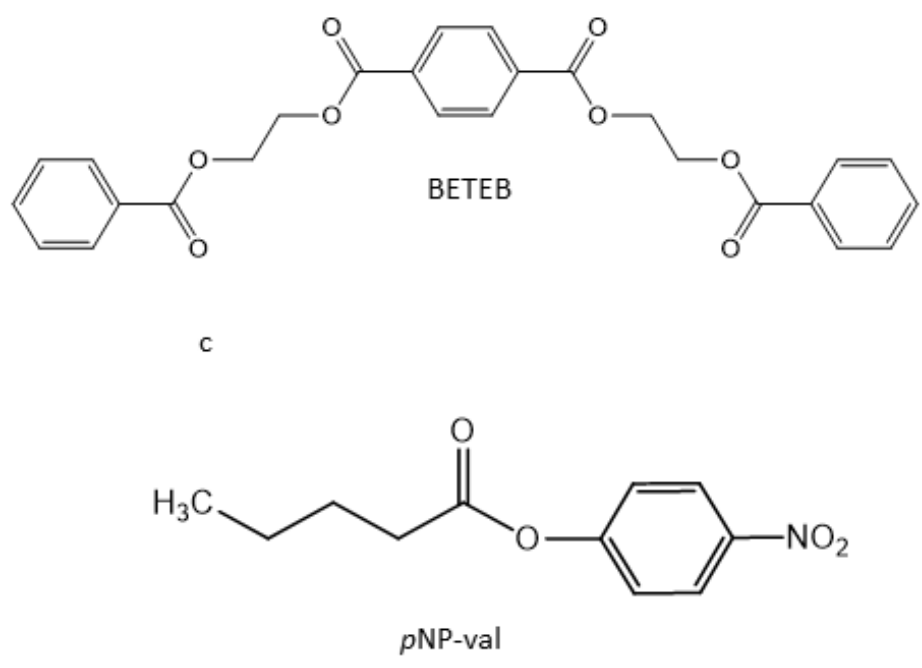

d

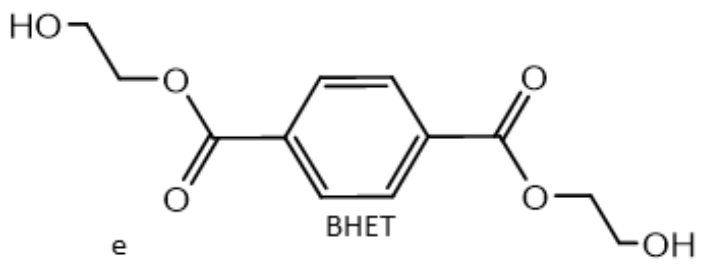

f
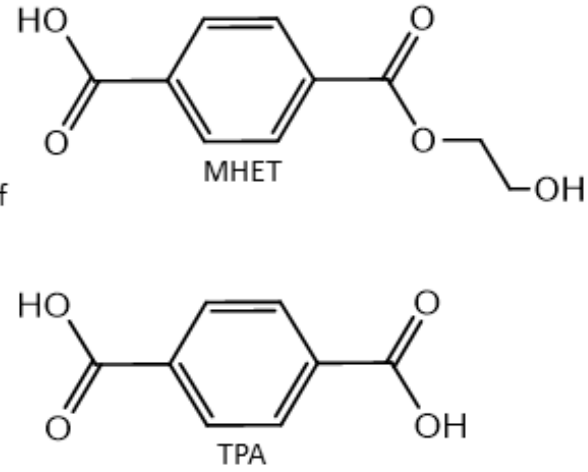

g

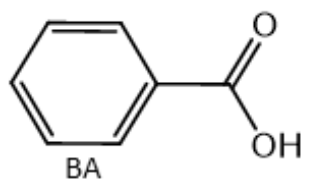

Figure 1. Substrates and products discussed in this study. a) Chemical structure of the intact PET polymer; b) In-house synthesized PET fragment, BETEB, with three aromatic rings; c) Conventional substrate analog, $p$ NP-val, for cutinases; d) PET fragment, BHET, with two ester bonds; e) The repeating unit, MHET, of the PET polymer; f) The unesterified diacid, TPA; and g) monoacid BA. BHET and MHET were both observed as reaction products from PET hydrolysis, but were additionally used as substrates. BA was a reaction product from BETEB hydrolysis reactions. TPA was observed as a minor reaction product from PET, BETEB, BHET and MHET hydrolysis and is the constituent monomer of the PET polymer. 

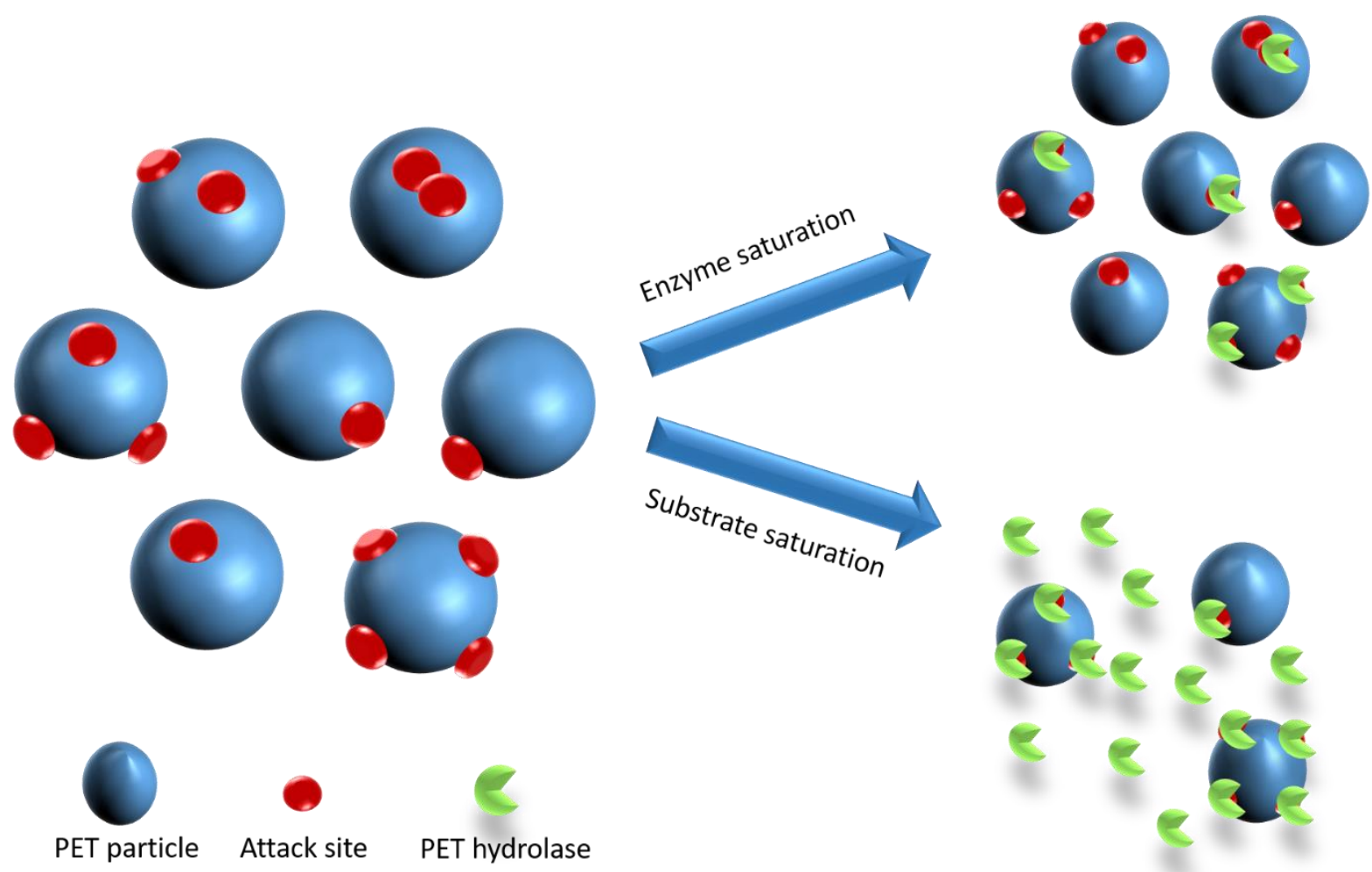

Figure 2. Schematic illustration of saturation under the two experimental conditions investigated here. The well-known, conventional Michaelis-Menten ( ${ }^{\mathrm{con}} \mathrm{MM}$ ) approach, uses an excess of substrate and initial rate measurements at a number of substrate loads. At high substrate loads, this leads to "enzyme saturation" where all enzyme is in a bound state. Conversely, the inverse $\left({ }^{\text {inv }} \mathrm{MM}\right)$ approach measures initial rates at a low substrate load and gradually increasing enzyme concentrations. This leads to "substrate saturation", where all attack sites on the substrate surface are occupied. 

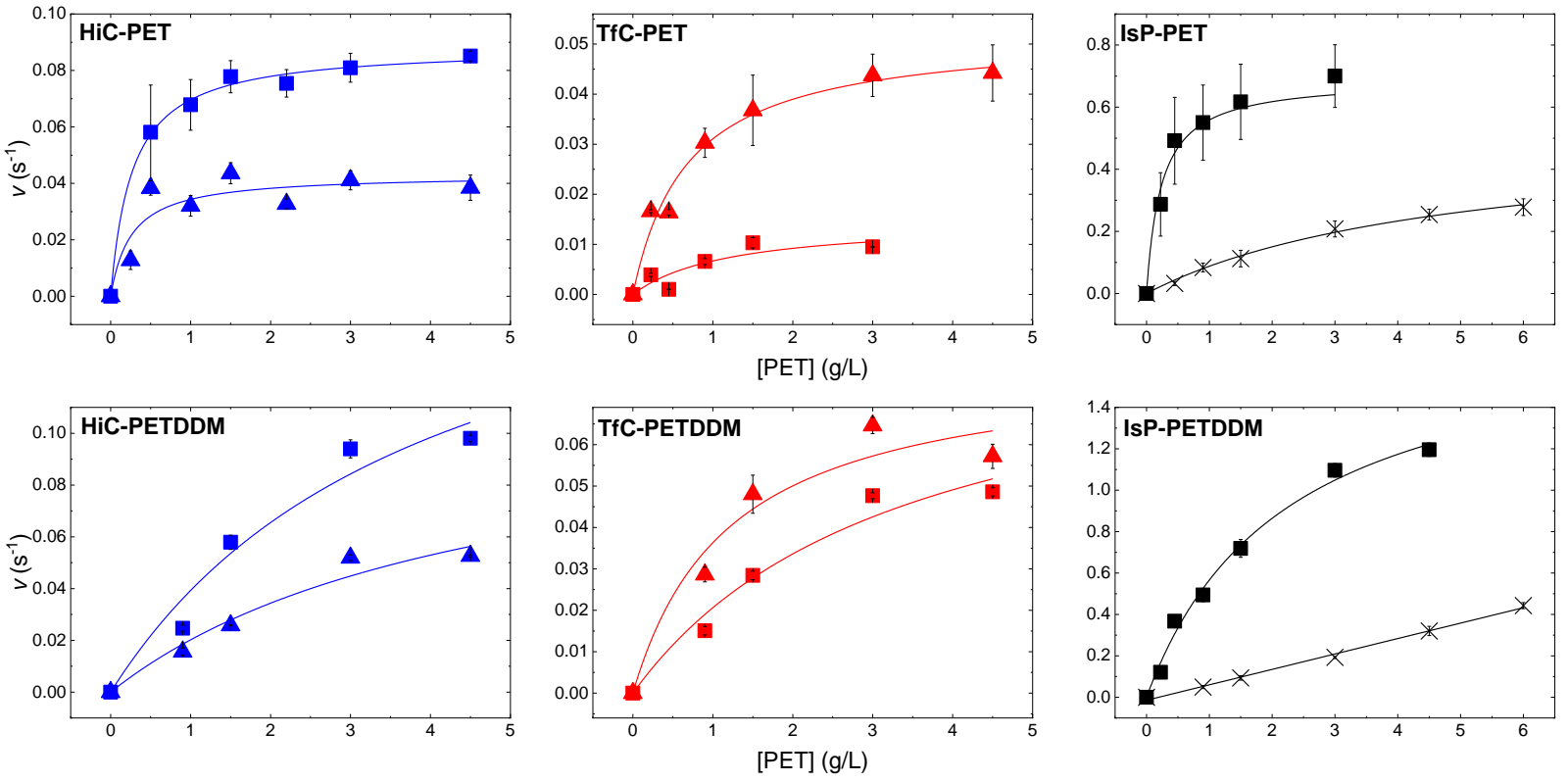

Figure 3. Conventional Michaelis Menten ( ${ }^{\mathrm{Con}} \mathrm{MM}$ ) plots for HiC (blue), TfC (red) and IsP (black). The curves show hydrolysis rates as a function of PET load in g/L. Symbols are experimental data from $2 \mathrm{~h}$ (IsP) or $5 \mathrm{~h}$ (HiC and TfC) reactions at $40{ }^{\circ} \mathrm{C}$ (crosses), $50{ }^{\circ} \mathrm{C}$ (squares) or $60{ }^{\circ} \mathrm{C}$ (triangles) with $0.03 \mu \mathrm{M}$ enzyme. Upper panels are without the addition of the nonionic surfactant n-Dodecyl $\beta$-D-maltoside (DDM). Lower panels are with $0.0025 \%(\mathrm{w} / \mathrm{V})$ DDM. Each enzyme was investigated at two experimental temperatures below their $\mathrm{T}_{\mathrm{m}}$. Error bars represent standard deviations of triplicate measurements and lines are the best fit of eq. (4). For IsP-PET with DDM at $40{ }^{\circ} \mathrm{C}, \mathrm{K}_{\mathrm{M}}$ was much larger than the highest substrate load and these data are fitted to a straight line. Parameters derived from these results may be found in Table 1 . 

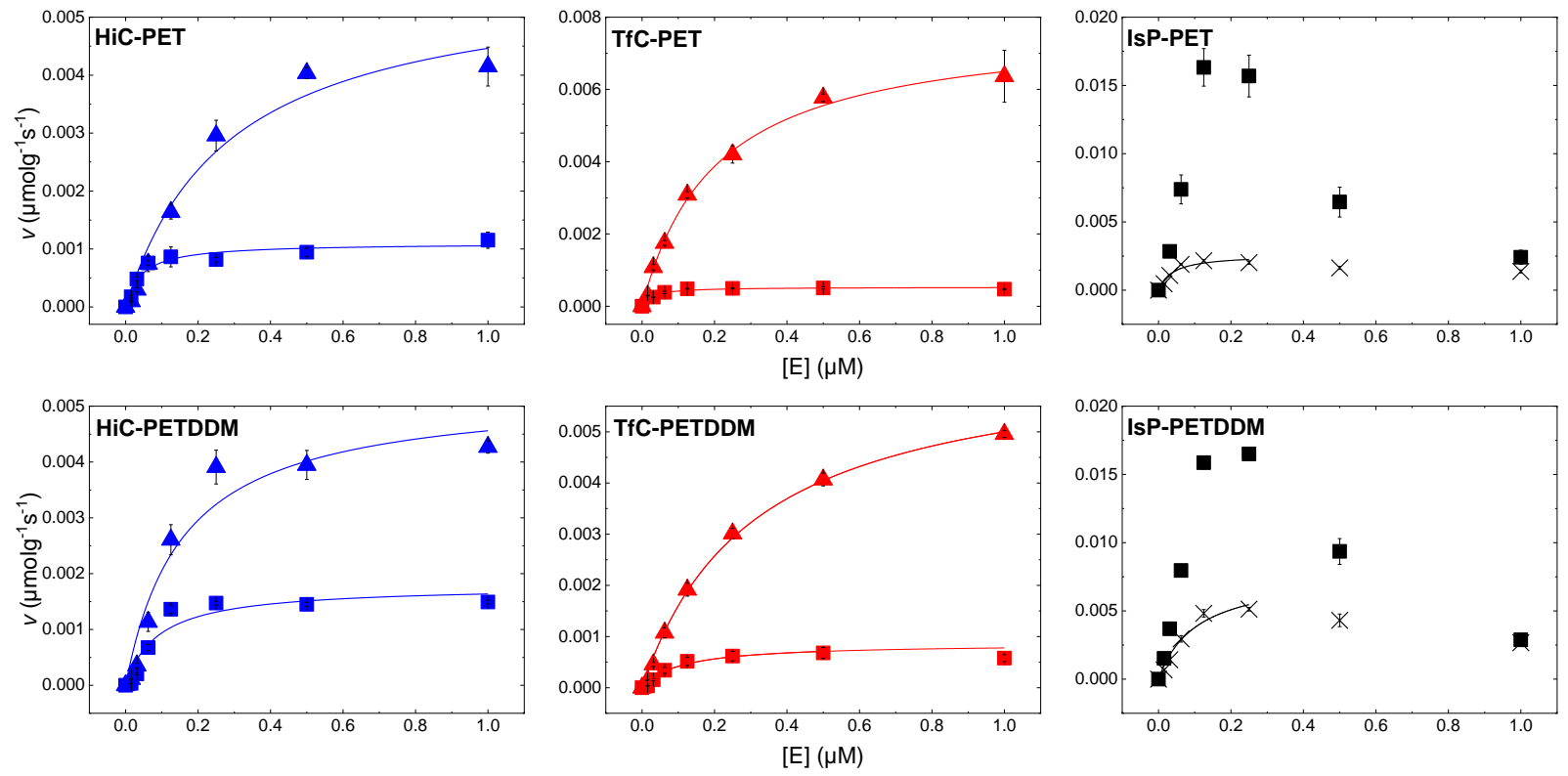

Figure 4. Inverse Michaelis Menten ( $\left.{ }^{\mathrm{Inv}} \mathrm{MM}\right)$ plots showing the hydrolysis rate as a function of enzyme concentration. Symbols are experimental data from $3 \mathrm{~h}$ reactions at $40{ }^{\circ} \mathrm{C}$ (crosses), $50{ }^{\circ} \mathrm{C}$ (squares) and 60 ${ }^{\circ} \mathrm{C}$ (triangles) with $10 \mathrm{~g} / \mathrm{L}$ PET. All symbols, colors and panel positions have the same meaning as in Fig. 3. Lines represent the best fit of eq. (5) and the derived kinetic parameters may be found in Tab. 2. IsP displayed a decline in activity upon high enzyme load and data for $50{ }^{\circ} \mathrm{C}$ were not possible to fit to eq. (5). IsP data for $40{ }^{\circ} \mathrm{C}$, where this effect was less pronounced, were fitted until the drop. 

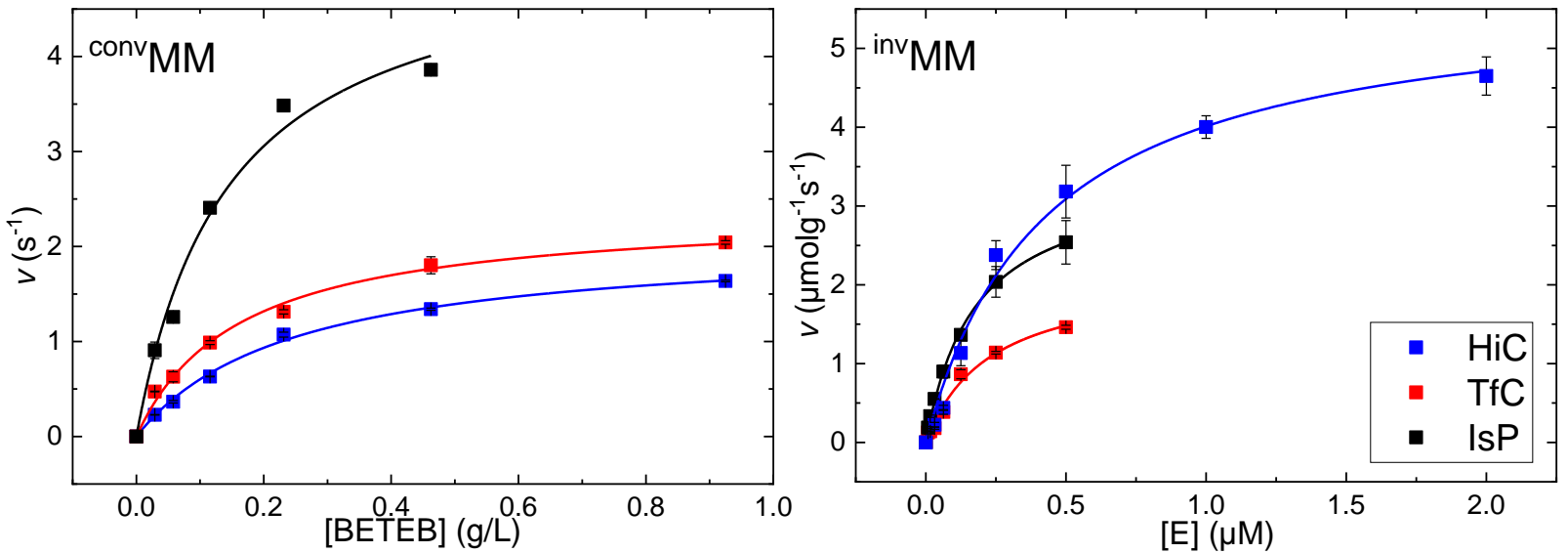

Figure 5. Conventional- and inverse MM plots for $\mathrm{HiC}$ (blue), TfC (red) and IsP (black), with initial hydrolysis rate as a function of BETEB or enzyme load. Symbols are experimental data from $10 \mathrm{~min}$ (IsP) or $20 \mathrm{~min}$ (HiC and $\mathrm{TfC}$ ) reactions at $50{ }^{\circ} \mathrm{C}$ with $0.01 \mu \mathrm{M}$ enzyme $\left({ }^{\text {conv }} \mathrm{MM}\right)$ or $0.09 \mathrm{~g} / \mathrm{L}$ BETEB $\left({ }^{\mathrm{inv}} \mathrm{MM}\right)$. Error bars represent standard deviations of duplicate measurements. Lines represent the best fit of the nonlinear MM equation. 